\title{
Lad sommerfuglene komme ud at flyve
}

\section{En vision for samskabelse om bedre velfærd og psykisk arbejdsmiljø med en sommerfugle-model og en platform mellem praksis og universitet}

\author{
Af Charlotte Bill *)
}

\begin{abstract}
Resumé
Bedre velfærd! Mere velfærd for pengene! Et godt psykisk arbejdsmiljø! Igennem de seneste år har der i den offentlige moderniseringsdebat været fokus på, at de økonomiske, faglige og menneskelige ressourcer optimeres i samarbejdet om velfærdsopgaven. Siden reformationen har der i Danmark været en tradition for, at selvejende og frivillige organisationer varetager en stor del af velfærdsopgaverne i samarbejde med den offentlige sektor. I de sidste 100 år har dette samarbejde gennemgået flere faser og til tider været spændingsfyldt. Samtidig diskuteres det, at det rummer mulighed for samskabelse og kreativ brug af ressourcer.
\end{abstract}

Artiklen bygger på en systemteoretisk analyse af et nyt større udviklings- og forskningsprojekt. Casen, der undersøges, er et fireårigt partnerskabsprojekt mellem 100 selvejende frivillige daginstitutioner, deres paraplyorganisation og tre kommuner, der skulle udvikle samarbejdet. Det vises, hvordan samarbejde med partnerskaber kan blive til samskabelse mellem selvejende frivillige daginstitutioner og det offentlige. Dette rummer et stort potentiale i forhold til at håndtere den kompleksitet, som velfærdsopgaven i dag kræver.

Analysen konkluderer, at hvis samarbejdet skal blive til samskabelse, må det imidlertid igennem en særlig transformationsproces. Som et bud på at guide denne proces præsenterer jeg en sommerfugle-model, der er udviklet på baggrund af analysen. Den viser, hvordan partnerskaber

*) Charlotte Biil er cand.jur., advokat, Master of Public Administration og tilknyttet Institut for Ledelse, Politik og Filosofi som ph.d.-stipendiat. 
mellem frivillige og offentlige organisationer på flere planer kan bidrage til en spirende ny praksis for samskabelse om velfærdsopgaven, og der gives et bud på, hvordan der kan skabes værdi i et spændingsfuldt samarbejde.

Med sommerfugle-modellen udpeges der ikke bare ét svar på ét problematisk og spændingsfyldt samarbejde. Det er derimod et normativt nedslag på arenaen af forskellige tilgange til problemer og løsninger på samarbejdets spændinger og udfordringer. Det understreges, at skal samarbejdet transformeres til samskabelse, må det hele tiden skabes, genskabes og udfolde sig relevant. Der argumenteres for en platform mellem praksis og universitet, der kan understøtte dette, for parterne må selv etablere forudsætningerne for transformationen.

Sommerfugle-modellen er også relevant for samarbejdet om psykisk arbejdsmiljø, for det spejler tilsvarende kompleksitet og håndtering af mange krav til velfærdsopgaven, der løbende forandrer sig, som når der skal arbejdes med Pernille Steen Pedersens nye anerkendelsespraksis, der adresseres i den anden artikel i dette nummer.

\section{Emneord}

Governance, netværk, partnerskab, samskabelse, velfærdsledelse 


\section{A. Indledning}

\section{Baggrund og problemstilling}

"Næste gang gør vi det anderledes". Jeg var lige startet som generalsekretær omkring 2007 for MDI (Menighedernes Daginstitutioner), paraplyorganisation for 100 selvejende daginstitutioner, da den første fusionsbølge ramte. Lederne brød sammen i lange baner med stress, depression og sygemeldinger, fordi de ikke kunne overskue fusionerne, og jeg blev kastet ud i en række menneskeligt, juridisk og økonomisk krævende afskedigelsessager. Jeg tog kontakt til kommunen og mødtes med direktøren for området og sagde, at "næste gang gør vi det anderledes". Det var hun enig i.

På dette tidspunkt var samarbejdet mellem selvejende og frivillige organisationer og kommuner om velfærd presset, og der var mange spændinger, som førte til, at samarbejdsaftalerne i stigende omfang blev opsagt. Ifølge det nordiske forskningsprojekt "Outsourcing of Scandinavian Welfare Society" faldt andelen af selvejende daginstitutioner i Danmark fra 32\% til 21\% i perioden 2000-2011 (Thøgersen 2013). En rapport fra de selvejende daginstitutioner viste, at der stort set ikke var oprettet nogen nye selvejende institutioner siden 1980'erne (Biil, Christiansen et al. 2007). Der var flere parter, som involverede sig i en politisk debat om udfordringerne i samarbejdet mellem selveje og kommuner, og hvorfor et fortsat stigende omfang af selveje blev lukket og gjort kommunale. Debatten kom til udtryk i presse, politiske tiltag og rapporter om emnet fra DLO (Daginstitutionernes Landsorganisation), Dansk Erhverv og deres brancheforening Selveje Danmark, Regeringen, Kommunernes Landsforening og Udbudsrådet. Samlet gav disse parter udtryk for, at de gerne ville et samarbejde, men ingen kunne pege på de rigtige betingelser for, at dette kunne lykkes. Parterne syntes både at ville og ikke ville et samarbejde, der var spændingsfyldt (Biil, Christiansen et.al. 2006, 2007; Højlund \& Biil 2015; Dansk Erhverv 2010, 2011 a, b og c, 2012; Udbudsrådet 2010, 2011; Konkurrencestyrelsen 2010; Regeringen 2011 a og b; Rambøll 2011).

Dette blev afsættet til en finanslovsbevilling i 2010 til det studerede MDI-partnerskabsprojekt, der indebar, at jeg selv blev tilknyttet som forsker på CBS og involverede langt større kompleksitet og flere interessenter, end jeg i min vildeste fantasi havde forestillet mig. Ud over de tre kommuner, 100 selvejende daginstitutioner og MDI kom projektet til at inddrage aktører fra Folketinget, Socialministeriet, Socialstyrelsen, faglige organisationer som BUPL, FOA, Dansk Erhverv, Selveje Danmark, KL, Det Danske Evalueringsinstitut (EVA), professionshøjskolen UCC og CBS (Højlund \& Biil 2015). Et projekt der varede fire år i perioden 2011-2015, og som indebar at ledelseslagene i de involverede daginstitutioner blev reduceret med op til 50\% med etablering af netværk og nye måder at samarbejde på om velfærdsopgaven. De selvejende daginstitutioner var med deres ledere, ansatte og frivillige bestyrelser selv med til at skabe det nye, og der var ingen dramatiske sammenbrud som i den første fusionsrunde. 
Selvom der hverken var lovgivning eller kontrakt, som forpligtede de direkte berørte 100 selvejende daginstitutioner og 3 kommuner til at indgå i det omfattende projekt, der med partnerskab skulle udvikle og afprøve et nyt samarbejde med dets mange aktiviteter, gjorde parterne det alligevel. Min erkendelsesinteresse blev rettet mod, hvordan jeg kunne forstå det samarbejde, der have udfoldet sig? Kunne det bane vejen for en anden måde at samarbejde på om velfærdsydelsen, der var mindre konfliktfyldt og ressourcekrævende for de involverede parter? Kunne det være muligt at undersøge og udvikle nye samarbejdsformer, der som samskabelse kunne forløse et potentiale?

\section{Oversigt over artiklen}

I det følgende beskrives kort den danske kontekst for samarbejdet mellem selvejende frivillige organisationer og det offentlige om velfærd, der er præget af ofte modsatrettede krav og en stigende kompleksitet. Der præsenteres teori om samarbejdet som samskabelse. Der introduceres et systemteoretisk perspektiv på partnerskaber med fokus på enkle, flygtige og foregribende koblinger, som betingelse for samarbejde med et hybridt samspil sat af forskellige samarbejds- og tidslogikker. Herefter gennemgås den analytiske tilgang, metode og det empiriske materiale. Analysens resultater vises fra det studerede partnerskabsprojekt mellem 100 selvejende daginstitutioner, deres paraplyorganisation og tre kommuner. Disse resultater diskuteres derefter med henblik på, hvordan samarbejdet kan transformeres til samskabelse. På denne baggrund udledes sommerfugle-modellen som en normativ tilgang, der kan bidrage til øget samskabelse om velfærdsopgaven understøttet af en platform mellem praksis og universitet.

\section{B. Teori om selveje, samarbejde og samskabelse}

I Danmark har samarbejdet mellem selvejende frivillige institutioner og det offentlige spillet en stor rolle i udviklingen af den danske velfærdsstat. Der er rødder tilbage til reformationen, hvor midler fra konfiskationen af den katolske kirkes ejendom blev investeret i selvejende velfærdsinstitutioner eller stiftelser, der på et non-profit grundlag i samarbejde med det offentlige skulle levere velfærdsydelser til børn, ældre og syge (Lund \& Berg 2016:10).

Da velfærdsstaten i sidste århundrede blev udbygget, blev mange sociale opgaver overtaget af det offentlige, men mange selvejende frivillige institutioner fortsatte deres arbejde i et samspil med det offentlige og typisk på områder, hvor det offentlige havde ansvaret for, at opgaverne blev løst. Et stort omfang af alle velfærdsopgaver løses stadig af selvejende velfærdsinstitutioner over den såkaldte driftsoverenskomst (Henriksen \& Bundsen 2004; Ibsen \& Habermann 2006:16; Thøgersen 2013). Der er imidlertid ikke tvivl om, at det i disse år både i praksis og teoretisk diskuteres, hvordan velfærdsopgaverne skal løses, og indretningen af et fremtidigt samspil mellem den private, frivillige og offentlige sektor (Aagaard, Sørensen \& Torfing 2014; Sørensen \& Torfing 2011, 2017; Wied 2010). 
Der er samskabelse på dagsordenen både hos frivillige selvejende organisationer, i den offentlige sektor og i den teoretiske governance litteratur. I Danmark siger 77\% af kommunerne, at de på den ene eller anden måde har været involveret i aktiviteter om samskabelse (OECD 2011; Hjære \& Jørgensen 2017). En nyere udvikling i forståelsen for samskabelse refererer til et paradigme, hvor netværk er det bærende, når det offentlige skal samarbejde med eksterne aktører om at løse velfærdsopgaver gennem samskabelse eller samstyring som et alternativ til stats- og markedsproduktion af offentlige ydelser (Pestoff 2006; Alford 2009; Bovaird og Löffler 2012; Sørensen \& Torfing 2017). Det fremhæves, at samskabelse som organisationsform er velegnet til at udvikle effektive løsninger på "wicked problems", altså problemer, der er kendetegnet ved høj kompleksitet, der involverer mange interessenter, og hvor der ikke er enighed om, hvori problemet består, eller hvordan det skal løses (Sørensen \& Torfing 2011). En sammenfattende definition lyder således:

\footnotetext{
"Samskabelse er, når offentlige aktører og borgere samarbejder om at udnytte alle parters aktiver, ressourcer og bidrag bedre for at opnå empowerment, større effektivitet eller bedre resultater."
}

(Tortzen 2019:58).

Med udgangspunkt i denne definition arbejder flere governance-forskere også med, at frivillige organisationer er centrale i at forløse potentialet i et samarbejde om velfærdsydelsen med det offentlige, men det er mindre klart, hvorfor dette netop skulle være tilfældet, og under hvilke betingelser et sådant samarbejde har størst sandsynlighed for at fungere (Pestoff, 2010:213; Pestoff m.fl., 2012; Osborne m.fl., 2010; Thøgersen, 2013; Tortzen 2019).

I Danmark er governance debatten om samarbejdet mellem selvejende og frivillige organisationer således præget af et strukturperspektiv og sektorblik, der vil definere civilsamfundet og dets organisationer som en tredje sektor i forhold til det offentlige og markedet (Toft Rasmussen \& KockNielsen 1996; Skov Henriksen 1996; 2007; Bundesen, Henriksen \& Jørgensen 2001; Fridberg \& Skov Henriksen 2014; Boje, Fridberg \& Ibsen 2006).

Sektorblikket synes imidlertid at komme til kort, når de selvejende institutioner i Frivillighedsundersøgelsen fra 2006 tolkes som en organisationsform, der er vanskelig at indfange og kategorisere (Ibsen \& Habermann 2006). Dette kan være med til at forklare spændingerne i samarbejdet mellem selvejende frivillige organisationer og det offentlige, fordi det er uklart, hvad der er relevante samarbejdsformer, og hvad disse kan bidrage med også i forhold til samskabelse. Nærværende artikel bygger i stedet på et systemteoretisk perspektiv som en anden tilgang til at beskrive samarbejdet mellem selvejende frivillige organisationer og det offentlige (Andersen \& Pors 2015:279-286; La Cour 2012, 2014a+b). La Cour viser, hvordan de frivillige organisationer i dag må 
gøre sig relevante som samarbejdspart ved konstant at være i en skabelsesproces med henblik på at kunne håndtere paradoksale og modsætningsfyldte krav til samarbejdet med det offentlige (2012:61, 2014b:470). Andre systemteoretiske forskere viser, at den ret, der regulerer samarbejdet, har udviklet sig med fire programmer for formel ret, substantiel ret, refleksiv ret og hybrid ret, som hver har deres særlige karakteristika i den måde, som et samarbejde kan iagttages på. Udviklingen i programmerne viser, hvordan retten uddifferentieres og gradvist trækker sig tilbage som hybrid ret og åbner sig for andre rationaler (Born et.al. 1988; Sand 2012:202-203; Andersen \& Pors 2014:180-187).

Med et systemteoretiske perspektiv bliver det muligt på en mere præcis måde at iagttage, hvornår samarbejde bliver til samskabelse mellem selvejende og frivillige organisationer og det offentlige. For hvordan man forstår et sådan samarbejde, og om det evner at levere et særligt velfærdspotentiale med samskabelse, afhænger for det første af, hvordan man vælger at iagttage, hvilket jeg gør med en systemteoretisk tilgang. For det andet afhænger det af, hvorfra man vælger at iagttage, hvilket jeg gør ved at kigge på et bredere felt af samarbejdets tilblivelsesprocesser inden for MDI-partnerskabsprojektets rammer.

Med denne tilgang var mit overordnede forskningsspørgsmål, hvordan en samarbejdsstruktur i det komplekse og krævende partnerskab kunne forstås, hvor dette umiddelbart syntes uforpligtende, men alligevel udviklede sig som hybridt temporaliseret samspil sat af formelle programmer og retslig semantik?

Forskningsspørgsmålet indebar, at jeg ville undersøge og indfange det nye samarbejdes emergerende, hybride og temporaliserede strukturer. Partnerskabet var ikke struktureret på forhånd, sådan som det var tilfældet med den driftsoverenskomst og dagtilbudslov, der også regulerede samarbejdet mellem selveje og kommuner, og som refererede tilbage i tid til dengang, kontrakten blev indgået mellem parterne. Snarere blev der tale om et samspil, der vekslede mellem de eksisterende strukturer for samarbejdet og nye, der udviklede sig rammesat af flere retslige programmer, der refererede til forskellige tidsligheder. Ved at aktivere andre måder at samarbejde på, blev samarbejdet i stand til at række frem i tid og håndtere det, der endnu ikke var tydeligt og ikke aftalt på forhånd i nogen kontrakt, men som alligevel var på vej som noget, der blev udpeget som relevant, og som det var nødvendigt at forholde sig til i samarbejdet. Med et hybridt temporaliseret samspil menes således en vekselvirkning mellem både de eksisterende strukturer for samarbejdet og dem, der kom til at udvikle sig.

Det var MDI-partnerskabsprojektet, der som struktur for samarbejde blev sat i centrum for analysen. Med en systemteoretisk analyse blev det holdt åbent, hvori et begreb om samarbejde bestod (Andersen 2006). Det analytiske perspektiv blev rettet mod den måde, partnerskabsprojektet med 
forskellige programmer kom til at regulere samarbejdet på anden vis, end kontrakt og lovgivning alene gjorde mulig, ved at stille nye samarbejdsstrukturer til rådighed igennem projektperioden. Disse kunne synes uforpligtende, men udviklede sig alligevel og skabte nye mulighedsbetingelser for samarbejde. Det kan lyde snørklet, men systemteorien gør det muligt at stille endog særdeles skarpt på de samarbejdssemantikker og koder, der aktiveres i forbindelse med organisationers samarbejde (Luhmann 2000).

Ifølge systemteorien er det moderne samfund polykontekstuelt, dvs. at der ikke er nogen enhed, hvorfra det kan iagttages (Sløk \& Villadsen et al. 2008). Dette betyder, at der ikke er noget autoritativt centrum, hvorfra samarbejdet mellem parterne styres. Systemteorien siger, at samfundet er opdelt i forskellige funktionssystemer. Disse producerer mening ud fra hver deres særlige logik og koder og er lukkede og selvreferentielle. Med koderne er der tale om den forskel, som et funktionssystem iagttager og konstruerer verden igennem (Luhmann 2000). Et samarbejde vil på forskellig vis koble funktionssystemer med forskellige koder, men der må opgives en forestilling om, at et system kan styre et andet. Et system er, ifølge systemteorien, både lukket og åbent. Systemer kan iagttage hinandens kommunikation og kan tilskrive hinandens kommunikation mening, men kun ud fra egne koder og kommunikationsformer.

Retssystemets kode er ret/uret. Den henviser til, om en kommunikation kan iagttages i systemet som retmæssig eller uretmæssig (Luhmann 1985, 1986; Højlund 2002; Andersen \& Pors 2014). Det politiske systems kode er styrer/styret, som sætter en social distinktion mellem den magtoverlegne og den magtunderlegne i den politiske kommunikation. Ifølge systemteorien kan den magtoverlegne overføre sin kompleksitet til den magtunderlegne, som må håndtere kompleksiteten og fortolke den magtoverlegnes intentioner. På den måde bliver magt et spørgsmål om at styre den styredes frihed til mægtiggørelse, altså at styre sig selv (Luhmann 1997, 2002; Andersen 2006; Andersen \& Pors 2014). Det økonomiske system iagttager verden gennem forskellen betale/ikke-betale eller have/ikke-have (Luhmann 2000:526-527; Andersen 2006). Omsorgssystemets kode er hjælp/ikkehjælp (Moe 1998; La Cour 2014a; Andersen \& Pors 2014). Det pædagogiske systems kode er bedre/dårligere indlæring (Luhmann 2000:384-385; Moe 2003:201, 216 note 4; Andersen \& Pors 2014). Kærlighedssystemets kode er elsket/ikke-elsket. Kommunikation, der betjener sig af denne kodning, skaber selv- og verdensbilleder, hvor det handler om at tage den anden på sig og tematisere det højst personlige (Andersen \& Born 2001:15; Luhmann 2012).

Med et begreb om strukturelle koblinger kan det imidlertid blive muligt at få øje på, hvilke interne strukturer de enkelte systemer må opbygge, for at de kan iagttage hinanden og gøre sig omverdensfølsomme for hinandens operationer og dermed de semantikker, der må mobiliseres i det enkelte system for at aktivere et samarbejde (Luhmann 2000, 2016). Med samarbejde mellem selvejende daginstitutioner og kommunerne forstår jeg således et begreb om hybrid organisering mellem 
organisationer, hvor de funderet i forskellige funktionssystemer kan indgå i forskellige former for samspil. Når jeg benævner det "samarbejde", er det for at indikere, at de strukturelle koblinger er blevet mere komplekse med rettens udvikling frem mod hybrid ret, og at meningsdimensionen $\mathrm{i}$ forhold til sag, socialitet og tid er i bevægelse.

Med partnerskab som ramme for et samarbejde med enkle og flygtige koblinger er jeg inspireret af flere systemteoretikere, der forstår et sådan samarbejde mellem organisationer som en særlig slags beslutninger. Først når de enkelte organisationer hver for sig har besluttet at gøre det, de snakker om på partnerskabsniveau, til beslutninger hos dem selv som individuelle organisationer, er der tale om beslutninger. Der kan imidlertid også være tale om mere flygtig beslutningskommunikation på partnerskabsniveau, hvor der ikke besluttes noget her og nu, men som alligevel informerer en potentiel beslutningshorisont, som der så senere kan besluttes eller ikke besluttes om (Teubner 1994, 1996, 2002; 2009; Andersen 2006, 2008, 2012; Andersen \& Pors 2014:180-187, 2016; Højlund \& La Cour 2008, Biil 2020: kapitel 5).

Deltagerne kan lade samarbejdet mellem sig som partnerskab pege i mange retninger. Hver organisation er både velkendt og sikker i sin egen form. Samtidig er denne bundet til de fælles målsætninger i partnerskabet. I forhold til samarbejde betyder det, at projektet får et dobbelt referencepunkt for hver deltager. Det giver de deltagende organisationer mulighed for at agere som en samlet krop i form af partnerskabet og som individuelle organisationer hver for sig (Biil \& Højlund 2015:22-23). Med enkle og flygtige koblinger konstitueres en særlig form for metastyring, der kan referere til flere systemlogikker og temporaliteter for samarbejde, hvor der ikke er noget autoritativt centrum, hvorfra styringen af dette udgår. Styringen afhænger af, hvordan de involverede organisationer knytter an til metastyringen og gør den til præmis for deres egen selvstyring.

Den foregribende kobling aktiverer samarbejdet som en "kærlighedssemantik", hvor begge parter tager den anden på sig og sætter sig i den andens sted som betingelse for beslutning. Der er altså ikke tale om, at organisationer nærer følelser eller forelsker sig i hinanden, men der ligger her i en særlig samarbejdssemantik, hvor begge parter fokuserer på at foregribe den anden og gøre dennes verden vigtig for en selv som organisation. Som foregribende kobling gør den noget ved begges identitet og dermed også ved samarbejdet (Philippopoulos-Mihalopoulos 2003:2, 2012:15; Biil 2020: kapitel 5).

Også med den foregribende kobling gives der afkald på et autoritativt center, men det er anderledes end med de enkle og flygtige koblinger. For med denne kobling drejer afkaldet sig om en beslutning, der ikke kan eller vil beslutte, hvornår denne er elsket nok af den signifikante andens forskellige 
ansigter eller de systemlogikker, der indsætter sig, og hvor langt den vil gå i forhold til at ændre sig selv for at kunne foregribe den anden.

\section{Metode og analytik}

Min metode var abduktiv og inspireret af Alvesson \& Kärremans mysteriemetode og Niklas Luhmanns funktionelle metode som program for forholdet mellem teori, metode og empiri (Alvesson \& Kärreman 2007; 2011:3,4,97; Luhmann, 1997:37; Knudsen 2011, 2014:31-36). Jeg søgte altså ikke at fiksere et begreb om samarbejde fra begyndelsen ved at konstatere og kortlægge "virkeligheden", for den ville være forblevet inden for de allerede kendte kategorier og forståelser herfor. Jeg forfulgte i stedet det, der emergerede som en ny måde at samarbejde på med partnerskabsprojektet, og som var uventede resultater. For at få et grundlag for at analysere empirien i forhold til denne erkendelsesinteresse udvidede jeg mit fokus til at omfatte et bredere felt af tilblivelsesprocesser af samarbejdet inden for partnerskabsprojektets rammer. Med Alvesson \& Kärreman søgte jeg at lave en følsom konstruktion, hvor både mine egne forforståelser inklusive min egen akademiske baggrund som jurist og forsker blev brugt som et værktøj til at åbne dialogen med det empiriske materiale (2007:1269).

Jeg var selv med til at konstruere de processer, der fik samarbejdets strukturer til at forandre sig i forbindelse med, at MDI-partnerskabsprojektets forskellige aktiviteter blev søsat. Dem har jeg forholdt mig undersøgende til ved at spørge ind til forskellige reguleringsforestillinger og idealer for samarbejde som led i konstruktionsprocessen og betone kontingens. Samtidig er en sådan proces umulig at indfange i sin helhed, og den må reduceres til en iagttagelse. Med et begreb om retslige programmer startede jeg med at grovsortere det empiriske materiale i forhold til denne kategorisering, da partnerskabsprojektet blev til, og der samtidig fandt en regulering sted af samarbejdet på forskellig vis med den driftsoverenskomst, der regulerede samarbejde, dagtilbudslovgivningen, lovgivers undersøgelse af samarbejdet med Rambøllundersøgelsen og den finanslovsbevilling og projektbeskrivelse, der beskrev betingelserne for det, der skulle blive til det studerede MDI-partnerskabsprojekt.

Samarbejdsproblematikken og konstruktionen af genstanden blev i min undersøgelse langsomt bygget op ved at åbne partnerskabsprojektets empiri med en systemteoretisk semantik- og programanalyse af dette empiriske materiale, hvor der blev taget udgangspunkt i en antagelse om, at forskellige retslige programmer afløste eller supplererede det hidtidige samarbejde over driftsoverenskomsten i retning af en anderledes form for regulering af samarbejdet mellem kommune og selvejende daginstitution. Semantikanalysens ledeforskel samarbejde/mening blev undersøgt med et begreb om samarbejde mellem selveje og kommuner. Hvordan det med forskellige 
retslige programmer fik tilskrevet mening i forhold til social-, sags- og tidsdimensionen omkring partnerskabsprojektets tilblivelse og kom til syne i det iagttagede iagttagende felt.

Retten gør det i udgangspunktet med sin regulering muligt at skabe forventninger til et samarbejde i nutiden og rette samarbejdet mod fremtiden som en særlig form for tidsbinding med koden ret overfor ikke-ret. Rettens kode er imidlertid ikke en konstant i forhold til, hvordan den skelner mellem ret og ikke-ret. Den er under forandring med nye reguleringsforestillinger fra formel, substantiel, refleksiv til hybrid ret (Born et.al. 1988; Sand 2012). Med et begreb om ret og retslignende programmer forstår jeg, at der formuleres bindinger i samarbejdet, hvor der knytter sig forskellige reguleringsforestillinger og idealer til det enkelte program (Andersen \& Pors 2014:175; Philippopoulos-Mihalopoulos 2010:74, 181).

Retten siges at blive hybrid, når den må oscillere mellem retten og andre sociale semantikker. Det drejer sig om, at den normative forudsigelighed, der normalt knytter sig til retten, udfordres af andre sociale systemer, der er rettet mod fremtiden og forandringer. Ikke mod erfaring og tidligere sager, hvilket normalt er rettens fokus. Sand peger særligt på, at retten får en mere og mere strategisk rolle. Dette indebærer, at retslige normer i stigende grad skabes og implementeres i heterogene, foranderlige, komplekse og mere krævende rum. Hun siger også, at der er behov for at tematisere den hybride ret (Sand 2012:202,203). Andersen \& Pors siger, at de er usikre på, hvordan den hybride ret skal defineres, men konstaterer, at den er en radikalisering af den refleksive ret, der sætter selve grænsen mellem ret og ikke-ret på spil i rettens form (Andersen \& Pors 2014:180-187). Med semantik- og programanalysen blev det muligt at få øje på, at der var fire retslige programmer i spil på samme tid, hvor partnerskabsprojektet som hybrid ret havde en ambition om at ville ændre, hvad sag, socialitet og tid i forbindelse med samarbejde mellem selveje og kommuner indebar. Det ville forandre det, der skulle samarbejdes om, trække nye personer ind, ændre aktørernes roller og få nye tidsmæssige horisonter i spil, og formulerede med en projektbeskrivelse et program herfor.

For at undersøge, hvordan den hybride ret udfoldede sig i den fireårige projektperiode med det studerede MDI-partnerskabsprojekt, tilføjede jeg med en koblingsanalyse semantik- og programanalysen yderligere nuancer ved at pege på de koblingsmekanismer, som partnerskabsprojektet i denne periode gjorde mulige at aktivere i forbindelse med samarbejdet mellem de selvejende daginstitutioner og kommunerne. Koblingsanalysens ledeforskel er kobling/differentiering og den form, der sætter betingelser for, hvilke koder der med den strukturelle koblingsmekanisme kan komme i spil, og hvordan dette sker.

Jeg forfulgte en tese om, at der var en strukturel sammenhæng mellem partnerskabsprojektet på policy niveau og det operationelle niveau. Til brug for koblingsanalysen opererede jeg med to overordnede kodningskategorier: 1) struktur for koblinger og 2) beslutningskommunikation. Til 
koblingsanalysen på policy niveau oprettede jeg et dokument, hvor jeg under kategorien "struktur for koblinger" anbragte citater, hvor kommunerne, selveje og MDI reflekterede over de rationaler, som lå til grund for deres beslutninger om samarbejde mellem selveje og kommunen og partnerskabsprojektets betydning. Jeg kategoriserede citaterne med koder inspireret af systemteoriens funktionssystemer.

Hurtigt stod det klart, at selvom parterne foretog de planlagte projektaktiviteter, så gik det langsommere med at etablere en ny samarbejdsmodel, og der opstod en beslutningskommunikation, der hverken ville beslutte eller ikke beslutte herom, som jeg forfulgte teoretisk med enkle og flygtige koblinger. Der emergerede to spor i kommunikationen, hvor særligt det sidste overraskede mig. Det første spor knyttede an til en traditionel politisk, økonomisk og juridisk logik med reminiscens fra driftsoverenskomsten, hvor der var tale om udveksling af en ydelse på bestemte vilkår mellem to parter og en styringsrationalitet fra kommunens side. Med det andet spor var der imidlertid blevet skabt en ny måde at stå i relation til hinanden på. Kodningsprocessen førte til, at samarbejdet blev afgrænset ved to kriterier: 1) det ene var en semantik, hvor parterne omtalte samarbejdet som en måde at styre den anden på, blive styret på eller tage en selvstyring på sig og 2) det andet var, at parterne omtalte samarbejdet i noget, der mindede om en kærlighedssemantik.

Opgaven blev derefter at undersøge, hvordan en styringsrationalitet kunne hænge sammen med det, der syntes at ligne en kærlighedssemantik i forhold til at begribe den samarbejdsrelation, der med partnerskabet indsatte sig, og de koblinger, der blev aktiveret. På den måde udviklede jeg en forståelse for 1) enkle og flygtige koblinger og 2) foregribende koblinger og det hybride samspil mellem disse, der fandt sted som nyt ideal for samarbejdet med partnerskabsprojektet. Jeg udviklede nu min teoretiske koblingsanalytik til både at omfatte enkle, flygtige og foregribende koblinger som en måde at undersøge de emergerende nye samarbejdsstrukturer på og gentog kodeprocessen. På den måde kom min koblingsanalyse til at træde mere og mere tydeligt frem og udfoldede en kommunikation mellem parterne kodet som 1) enkle og flygtige koblinger og med 2) foregribende koblinger, som jeg både undersøgte den kommunikation med, der udfoldede sig på et policy niveau mellem parterne og en konkret case på operationelt niveau i Svendborg kommune.

\section{Det empiriske materiale}

Analysen byggede på empirisk materiale fra partnerskabsprojektet, der var genstanden i mit PhDprojekt (Højlund \& Biil 2015; Biil 2020). Det blev indsamlet gennem 10 år i perioden 2005-2015 i forbindelse med min ansættelse som generalsekretær hos Menighedernes Daginstitutioner (MDI). Materialet var omfattende og blev organiseret i forhold til, om det refererede til samarbejdet mellem 
selvejende frivillige organisationer og det offentlige i det studerede partnerskabsprojekt på policy og operationelt niveau, til diskussioner og debatter i feltet om samarbejdet, der gik forud for etablering af projektet og relevant lovgivning og kontrakter, der ville regulere samarbejdet.

\section{Empirisk materiale til semantik- og programanalysen}

Det empiriske materiale til semantik- og programanalysen refererede til forskelligt materiale, der regulerede samarbejdet på det tidspunkt, da partnerskabsprojektet blev til omkring 2010-2011.

I den første kategori "den formelle ret" indsamlede jeg dokumentstudier af et stadig mere konfliktfyldt samarbejde mellem selveje og kommuner over driftsoverenskomsten. Dette i forbindelse med konkrete sager i kommunerne og som led i politiske debatter mellem parterne og interessenter, hvor jeg selv var debattør på vegne af de selvejende daginstitutioner. Det empiriske materiale bestod af standard driftsoverenskomsten, der i denne periode regulerede samarbejdet mellem selveje og kommuner, tilknyttet lovgivning og dokumenter og rapporter omkring nogle af de sager og debatter, som jeg var involveret i.

I den anden kategori "den substantielle ret" indsamlede jeg dokumentstudier af den dagtilbudslovgivning, der satte de overordnede formål og betingelser for daginstitutioner i Danmark i perioden, og som understøttede reguleringen i driftsoverenskomsten af samarbejdet mellem selveje og kommuner. Den dagtilbudslovgivning, jeg refererede til i forbindelse med det studerede partnerskabsprojekt, er den, der var gældende i forbindelse med projektet, dvs. i perioden 20052015. Lovgivningens historik frem til en opdateret version op til i dag kan findes på www.socialministeriet.dk.

I den tredje kategori "den refleksive ret" indsamlede jeg dokumentstudier i forbindelse med den finanslov, der i 2006 blev givet til en undersøgelse af selvejende daginstitutioners rammevilkår, der mundede ud i en rapport i 2011, hvor retten begyndte at blive refleksiv omkring sin egen indretning af reguleringen af samarbejdet mellem selveje og kommuner i medfør af driftsoverenskomsten og dagtilbudslovgivningen.

I den fjerde kategori "den hybride ret" var der tale om et dokumentstudie af den finanslovsbevilling, der i 2010 og 2011 blev anledning til en bevilling og formulering af en projektbeskrivelse til et partnerskabsprojekt mellem 100 selvejende daginstitutioner, tre involverede kommuner og MDI.

\section{Empirisk materiale til koblingsanalysen}

Det empiriske materiale til koblingsanalysen refererede til, hvordan MDI-partnerskabsprojektet udfoldede sig og blev sparret af en række interessenter i perioden 2011-2015. 
På et policy niveau skulle en koordinationsgruppe bestående af MDI, CBS, Socialministeriet, Socialstyrelsen og EVA sikre, at projektets aktiviteter blev søsat, hvor der blev sat to styringshorisonter med projektbeskrivelsen og indsatsteorien: a) én styringshorisont for et eksperiment, hvor partnerskabsmodellen med etablering af netværk skulle afprøves i tre kommuner og b) én policy horisont for udvikling af en ny samarbejdsmodel. En kommunestyregruppe og et advisory board med parterne, koordineringsgruppen og interessenter fra feltet som BUPL, Selveje Danark, Dansk Erhverv, professionshøjskolen UCC og Foreningen af Socialchefer skulle sparre projektet. Empirisk materiale var:

- Projektbeskrivelsen

- Bevillingsskrivelsen

- Kontrakt mellem MDI og EVA

- Kontrakt mellem MDI og CBS

- Indsatsteori og styringsdokument

- Løbende statusrapporter

- Mødematerialer og referater

- Transkriberede udskrifter fra kommunestyre og advisory board møder

- Formidlingsplan

- På operationelt niveau

På et operationelt niveau blev de 100 selvejende daginstitutioner etableret som 16 netværk i de tre kommuner. Empirisk materiale var:

- Uddannelsesplan på diplomniveau til lederne og deres eksamensopgaver

- Samspilsdokumenter mellem MDI og UCC

- Bestyrelseskursusmateriale fra MDI

- Netværkskontrakter, forretningsplaner, udviklingsaftaler og strategipapirer mellem daginstitutioner

- Driftsoverenskomster og evt. partnerskabsaftale

- Kvalitetsmålinger

- Interviews med Svendborg kommune og det selvejende daginstitutionsnetværk Fyrtårnet

\section{E. Hybrid ret bliver til på daginstitutionsområdet}

I det følgende præsenteres semantik- og programanalysen af det studerede MDIpartnerskabsprojekt. Der tages udgangspunkt i en antagelse om, at forskellige retslige programmer 
afløste eller supplererede det hidtidige samarbejde over driftsoverenskomsten i retning af en anderledes form for regulering af samarbejdet mellem kommune og selvejende daginstitution, og det vises, hvordan de forskellige programmer fik tilskrevet mening i forhold til social-, sags- og tidsdimensionen omkring partnerskabsprojektets tilblivelse og kom til syne i det iagttagede iagttagende felt.

\section{Dagtilbudsloven som substantiel ret}

Dagtilbudsloven var indrettet som substantiel ret, hvor kommunen kunne forfølge bestemt retsligt fastlagte formål i forhold til daginstitutionerne i kommunen, og den fastsatte kommunens mål og rammer herfor, jf. dagtilbudslovens $\S 3$ stk.1 og 2 og $§ 5$. Kommunen havde ifølge dagtilbudslovens $\S 4$ en forsyningsforpligtelse. Dette indebar, at kommunen skulle sikre det nødvendige antal pladser i dagtilbud, så alle kommunens børn kunne få tilbudt en plads inden for rammerne af pasningsgarantien. Daginstitutionerne kunne drives som kommunale, private eller selvejende daginstitutioner. På socialdimensionen var parterne kommunen og den selvejende daginstitution. Sagen drejede sig om daginstitutionsdrift. Temporaliteten refererede til de betingelser for samarbejde, der normativt bagud var blevet fastsat i driftsoverenskomst med reference til lovgivningen.

\section{Driftsoverenskomsten som formel ret}

Igennem årtier havde samarbejdet mellem de selvejende daginstitutioner og kommuner været reguleret af den såkaldte standard driftsoverenskomst, hvor socialdimensionen satte parterne som kommunen og den selvejende daginstitution med reference til dagtilbudsloven. Standard driftsoverenskomsten bestemte institutionens budget, antal børn, hvordan personale kunne ansættes og afskediges, løn- og ejendomsforhold og refererede til dagtilbudslov og kommunens børnepolitik i forhold til krav til institutionsdriften. Sagsdimensionen handlede om, at den selvejende daginstitution skulle passe børn på bestemte vilkår og dermed ligne den kommunale daginstitution med reference til en bagudrettet temporalitet som fastsat dengang, driftsoverenskomsten blev underskrevet.

\section{Refleksiv ret åbner op for partnerskabsprojektet}

I 2006 gav finansloven en bevilling til at undersøge de selvejende daginstitutioners vilkår og rammebetingelser. Det tog et par år, før undersøgelsen for alvor kom i søen, hvor den i 2010 endte med at blive varetaget af konsulenthuset Rambøll for Socialministeriet og håndholdt af en følgegruppe bestående af BUPL, FOA, KL, MDI, Frie Børnehaver og DLO. Socialministeriet varetog sekretariatsfunktionen og styrede undersøgelsen, der blev gennemført af Rambøll i perioden juni 2010 til marts 2011. Løbende havde undersøgelsens følgegruppe mulighed for at se og kommentere, hvad rapporten resulterede i. 
Formålet med Rambøllundersøgelsen var "at efterprøve lovgivers intentioner om at give muligheder for variation, konkurrence og frit valg på dagtilbudsområdet", der dermed pegede på et andet ideal for samarbejdet i sagsdimensionen end ovenfor, hvor den selvejende daginstitution skulle ligne den kommunale. Med undersøgelsen havde lovgivers intention ændret sig i forhold til et krav om variation på daginstitutionsområdet, og at den selvejende daginstitution skulle bidrage med noget andet end den kommunale. Selveje skulle være selvstændigt. De selvejende daginstitutioner var særligt udfordret på to dimensioner (Rambøll 2011:16). For det første syntes det vanskeligt for dem at indløse det nye ideal om at skulle være noget andet end det kommunale daginstitutionsmiljø. For det andet havde de selvejende daginstitutioner svært ved at indløse krav til stordriftsfordele sammenlignet med de kommunale daginstitutioner.

Den ovenfor beskrevne formelle og substantielle ret med driftsoverenskomst og dagtilbudslov var imidlertid samtidig i spil. Dette indebar som analyse, at der med Rambøll undersøgelsen samlet set dukkede et mere krævende ideal op fra det offentliges side for sagsdimensionen, hvor den selvejende organisation både skulle være selvstændig og gøre, hvad det offentlige sagde, som betingelse for samarbejde mellem socialdimensionens selveje og kommune.

Rambøll konstaterede, at samarbejdet mellem de selvejende daginstitutioner og kommunerne var præget af et relativt højt konfliktniveau (2011:22).Med udsagn om, at én væsentlig forklaring til det høje konfliktniveau lå "i det forhold, at hvor dagtilbudsområdet styringsmæssigt har udviklet sig kraftigt inden for de seneste 10-15 år, har de konkrete aftaleforhold, som i væsentligt omfang fastlægger parternes rettigheder og forpligtelser i forbindelse med egentlige konflikter, ikke udviklet sig tilsvarende" (Rambøll 2011:23) pegede analysen også på, at retten ikke havde magtet at være ret på området i forhold til at regulere samarbejdet mellem selveje og kommuner.

Samtidig udskød Rambøllrapporten også mere håndfaste beslutninger om, hvordan en fremtidig regulering skulle indrettes, ved at henvise til en forestående dialog mellem parterne, hvor der blev beskrevet flere mulige veje for en sådan dialog. Med udsagnet, "Rambøll har i beskrivelsen af partnerskabsvejen ovenfor helt bevidst placeret initiativet hos parterne, dvs. hos organisationerne, i praksis KL og paraplyorganisationerne", anbefalede denne, at reguleringen trak sig tilbage og antydede, at socialdimensionen kunne komme i bevægelse. Indtil nu havde socialdimensionen for samarbejde kun drejet sig om kommune og selveje. $\mathrm{Nu}$ blev der inddraget flere potentielle interessenter fra et mere overordnet policy niveau.

Normalt var det Socialministeriet, der forvaltede retsgrundlaget for samarbejdet mellem de selvejende daginstitutioner og kommuner i medfør af dagtilbudsloven. Analysen viser, at retten blev refleksiv og med en anbefaling om at etablere partnerskab indikerede, at der for det første kunne komme en bevægelse i spil i forhold til en sagsdimension, hvor selveje skulle levere en 
daginstitutionsydelse, der både gjorde som kommunen sagde, men også var selvstændig. For det andet kunne der komme en bevægelse i forhold til parterne på socialdimensionen, hvor det var relevant at inddrage flere interessenter. For det tredje var også temporaliteten $\mathrm{i}$ samarbejdet $\mathrm{i}$ potentiel bevægelse, fordi der med partnerskab som medie for et nyt samarbejde, skulle kunne indsætte sig andre funktionssystemer end rettens, der refererede til andet end en bagudrettet tidshorisont med juridisk kode i form af kontrakt og lovgivning. Med partnerskab som fundament for samarbejde kunne der blive tale om en ret, der for at være ret måtte trække sig tilbage fra at udøve den og åbne døren for, at andre funktionssystemer kunne træde op, hvor både social-, sagsog tidsdimensionen ville være i bevægelse. Med denne anbefaling var stafetten givet videre til det, der i 2010 resulterede i en finanslov med en bevilling til det studerede MDI-partnerskabsprojekt.

\section{Partnerskabsprojektet som hybrid ret}

Med Finansloven (2010:26) gav Folketinget en finanslovsbevilling til et partnerskabsprojekt mellem kommunerne Aarhus, Svendborg, København, 100 selvejende daginstitutioner og paraplyorganisationen MDI (projektbeskrivelsen 2011) med reference i projektbeskrivelsen til Rambøllundersøgelsens anbefaling om partnerskab (2011).

Årsagen til det konfliktfyldte samarbejde beskrev projektbeskrivelsen var, at de selvejende daginstitutioner gennem de seneste år var blevet udfordret på bæredygtighed ledelsesmæssigt, økonomisk og pædagogisk, samt i forhold til inddragelse af civilsamfund. Kommunerne stillede som politisk system krav om bæredygtighed for at kunne give retten informationer til at afgøre ikkeret/ret i forhold til, om samarbejdet med de selvejende daginstitutioner skulle fortsætte. Rettens kode blev altså vendt om med kravene om bæredygtighed. De selvejende daginstitutioner måtte kunne dokumentere sig inden for forskellen ikke-bæredygtig/bæredygtig til afgørelse af ikkeret/ret. Bæredygtighedslogikken blev på den måde udtryk for noget ikke-retsligt, der var afhængigt af noget retsligt, men som forvandlede det til et spørgsmål om bæredygtighed i de systeminterne operationer i forbindelse med samarbejdet.

Med partnerskabsprojektets projektbeskrivelse ændrede semantikken om samarbejdet karakter med en temporalisering af den saglige og sociale meningsdimension, fordi man både ville drifte daginstitutionerne og også udsætte dét, som det handlede om - betingelserne for samarbejdet. Med fire programmer i spil samtidigt blev retten uddifferentieret i forskellige hensyn/koder, som forskød retten til, at den ikke længere kun handlede om regulering af samarbejdet, men også om retten og pligten til at deltage i udviklingen af dette. Hermed blev der etableret en paradoksal spænding for samarbejdet, der både ville være ret og ikke-ret på én gang. Det etablerede nye temporaliserede strukturer, der kunne referere både til samarbejdet, som det var blevet formuleret i en fortid, men også til, hvordan det kunne blive i en fremtid. Som hybrid ret havde partnerskabsprojektet en ambition om både at ville opretholde og ændre, hvad sag, socialitet og tid 
i forbindelse med samarbejde mellem selveje og kommuner indebar. Dermed var der lagt op til, at det der skulle samarbejdes om kunne forandre sig, hvor der kunne blive trukket nye personer ind, aktørernes roller kunne ændre sig, og der kunne komme nye tidsmæssige horisonter i spil for samarbejdet.

\section{F. Den hybride ret folder sig ud med partnerskabsprojektet}

I det følgende præsenteres koblingsanalysen af det studerede MDI-partnerskabsprojekt, der tilføjer semantik- og programanalysen yderligere nuancer i forhold til at undersøge, hvordan den hybride ret udfoldede sig i den fireårige projektperiode, og hvilke koblingsmekanismer, det gjorde muligt at aktivere i forbindelse med samarbejdet mellem de selvejende daginstitutioner og kommunerne som et nyt ideal for samarbejde.

Igennem hele partnerskabsprojektets periode var der på policyniveau løbende kommunestyremøder og advisory board møder, som havde til formål at følge partnerskabet, samt være en slags refleksiv overbygning til partnerskabet og et sted, hvor der blev tænkt tanker af betydning for samarbejdets udvikling. Der kunne de deltagende parter formulere identitet i forhold til hinanden og det fælles partnerskabsprojekt, hvor det samarbejde der med projektet udviklede sig på et horisontalt og vertikalt niveau, kunne sætte retning for hinanden.

Da partnerskabsprojektet i 2012 havde været i gang i et års tid, begyndte Svendborg kommune at komme særligt til syne på disse møder i forhold til, hvordan et nyt samarbejde mellem selvejende daginstitutioner og kommuner med reference til det overliggende partnerskabsprojekt kunne afløse og supplere den hidtidige forståelse heraf med driftsoverenskomsten. Fordi udmeldingen kom på et advisory board møde, satte kommunen med sin udmelding en potentiel fremtidshorisont ikke kun på operationelt, men også på policy niveau for, hvad dette kunne indebære.

\section{Et nyt ideal for samarbejde mellem selveje og kommune bliver til}

"Vi øver os, og vi har en første udgave af den der partnerskabsaftale."

(kommunal chef fra Svendborg på advisorymøde den 5. december 2012).

Svendborg kommune havde lavet en ny partnerskabsaftale med det selvejende daginstitutionsnetværk Fyrtårnet, men den kommunale chef understregede samtidig med udsagnet, "Vi øver os, og vi har en første udgave af den der partnerskabsaftale”, at det nye samarbejde endnu ikke var endeligt og stabilt på samme måde som det samarbejde, der refererede til en driftsoverenskomst, der var blev indgået engang i fortiden. Den pædagogiske kode var aktiveret, hvor der bag kommunens udsagn lå, at de selvejende daginstitutioner skulle være modtagelige for 
læring og udvikling. Udsagnet indeholdt et løfte om udvikling af samarbejdet, men kunne lige så godt ende ud i et tidligere mere problematisk samarbejde mellem kommunen og det selvejende daginstitutionsmiljø over driftsoverenskomsten og dagtilbudsloven.

Partnerskabsprojektet blev hermed medie for at aktivere enkle og flygtige koblinger, der fik beslutningen om samarbejde mellem selveje og kommuner til at ville være noget andet i et fremtidigt samarbejde, end det var for indeværende alene med reference til driftsoverenskomst og dagtilbudslov. Det var en beslutning, som stræbte efter at være noget andet, men som ikke endnu var det. Med forskellen ikke-beslutning/ beslutning om etablering af et nyt samarbejde blev det potentielle beslutningsgrundlag imidlertid informeret, men forblev en ikke-beslutning, hvor parterne øvede sig på, hvad et nyt samarbejde kunne indebære i fremtiden. Hermed skete der altså en temporalisering af samarbejdet, der nu ikke alene refererede bagud i tid til dengang, det var blevet aftalt med driftsoverenskomsten, men som også rakte ind i en fremtid, som endnu ikke var ankommet, men som parterne øvede sig på.

Den første sag, som den kommunale chef havde haft i kommunen, fortalte hun, havde drejet sig om den selvejende daginstitution Mariasøstrenes børnehave, der var medlem hos MDI. Der havde været konflikt mellem institutionens formand, den lokale præst og kommunen om betingelserne for at drive denne.

Fra 2008 havde det konfliktfyldte samarbejde mellem kommunen, Mariasøstrenes børnehave og MDI imidlertid ændret sig, foranlediget af, at der var behov for at udbygge og renovere den pågældende børnehave med en vuggestuegruppe. Parterne etablerede en ny måde at samarbejde på over de næste år i forbindelse med udbygningen af institutionen. Det havde været et projekt, som skulle udvikles undervejs. Det havde ikke ligget fast på forhånd, hvordan det skulle udmønte sig, men det var lykkedes at komme i mål med udbygningen og et godt samarbejde herom.

I stedet for at ville styre hinanden var samarbejdet omkring Mariasøstrenes børnehave blevet anledning til, at parterne havde etableret hinanden som omverden i samarbejdet om at udbygge institutionen og forpligte hinanden på den større institution. Den politiske kode var blevet aktiveret, hvor kommunen trådte tilbage fra styringen af de selvejende, mens selveje omvendt havde taget selvstyring og mægtiggørelse på sig i forhold til ombygningen. Det var et samarbejde, hvor begge parter løbende havde foregrebet hinandens behov og fundet løsninger.

Analysen viser, at der skete en aktivering af foregribende koblinger, hvor selveje og kommune havde internaliseret hinanden som omverden, hvilket gjorde noget radikalt ved beslutningskommunikationen mellem disse. Som en kærlighedssemantik havde parterne spejlet hinanden i form af en suspensionsproces, hvor de rakte ud efter hinanden for så at række tilbage i 
sig selv. Derefter blev denne suspension suspenderet, og parterne kom tilbage til sig selv på en ny måde.

Ombygningssagen blev medie for et samarbejde, der ikke kun refererede til juridiske og økonomiske betingelser for samarbejdet i forhold til driftsoverenskomsten, da den var blevet indgået. Den aktiverede også enkle og flygtige koblinger i en vekselvirkning med foregribende koblinger og kom dermed til at blive udtryk for et nyt ideal for samarbejde med forskellige strukturer. Disse kunne række bagud i tid og referere til økonomiske og juridiske koder med driftsoverenskomst og lovgivning, men de kunne også række fremad i tid med andre samarbejdslogikker til at foregribe og håndtere de udfordringer, der var på vej i samarbejdet. Svendborg kommune forklarede, at denne sag gjorde, at kommunen nogle år senere gik ind i MDI-partnerskabsprojektet med en forventning om, at en tilsvarende ny horisont for samarbejdet kunne blive mulig mellem selveje og kommunen med projektet.

Denne kommunikation, der udfoldede sig på advisory board mødet, blev anledning til, at de to andre kommuner Aarhus og København på efterfølgende møder diskuterede det nye ideal for samarbejde mellem selveje og kommune. Idealet blev dermed udfordret, fik tilskrevet ny mening og blev forskudt samtidig med, at det også trak en grænse herfor.

\section{Grænsen for det nye samarbejde trækkes}

"Jeg skal sige lidt om erfaringerne fra partnerskabsprojektet og erfaringerne fra selveje i det hele taget. Det var jo meget optimistisk det, som Birgit fra Svendborg kommune sagde sidst. Jeg er så måske den mindst optimistiske af de tre kommuner."

(kommunal chef fra Aarhus advisory board møde den 17. april 2013)

Med den kommunale embedsmands udsagn "Jeg er så måske den mindst optimistiske af de tre kommuner" lå der både en reference til den horisont for en ny partnerskabsmodel på policyniveau og på det operationelle niveau, som Svendborg kommune havde sat på det sidste møde, men også, at dette så anderledes ud fra Aarhus kommunes perspektiv. For Aarhus kommune var partnerskabsprojektet ikke umiddelbart blevet anledning til, at der var etableret et nyt ideal for samarbejde mellem selveje og kommune. De selvejende daginstitutioner var en selskabskonstruktion og en historisk reminiscens, og partnerskabsprojektet havde været en måde at håndtere en besparelse på.

"Vi tænker, at selveje kunne blive en særlig udviklingsdynamo."

(kommunal chef fra Københavns kommune på advisory board møde den 23. oktober 2013) 
En kommunal chef fra Københavns kommune sagde på et efterfølgende advisory board møde, at "vi tænker, at selveje kunne blive en særlig udviklingsdynamo”. Han forklarede, at kommunen havde vendt sin organisation på hovedet og skabt et begreb om en udviklingsdynamo, der ikke nødvendigvis skulle findes inde i forvaltningen, men ude på den enkelte skole eller dagtilbud, hvor de gode spæde ideer skulle samles op og understøttes centralt. På den måde kunne samarbejdet med de selvejende daginstitutioner i fremtiden fungere som en særlig udviklingsdynamo i forhold til både sagsdimensionen om driften af daginstitutionen og socialdimensionen, om hvem der var involveret heri. Der var potentialer i et nyt samarbejde mellem selveje og Københavns kommune, der kunne demonstrere bæredygtighed pædagogisk, økonomisk og ledelsesmæssigt og involvere civilsamfund med enkle, flygtige og foregribende koblinger. Det var imidlertid et ideal for samarbejde, der ikke kunne sættes på en generel form i kommunen, for det stillede store krav til alle parter. Selvom de selvejende daginstitutioner var blevet for ens med de kommunale tilbud, var der også grænser for, hvor anderledes selveje måtte være. Det hele kunne blive for ustyrligt for kommunen.

\section{Det nye samarbejdes potentiale prøves af}

Et konkret eksempel på, hvordan det nye samarbejde kunne folde sig ud på lokalt plan, skete i forsommeren 2012, hvor strukturerne for en ny måde at samarbejde på blev afprøvet, da den ældre dame Erna gav sin kolonihave som gave til det selvejende daginstitutionsnetværk Fyrtårnet $\mathrm{i}$ Svendborg.

Når fast ejendom som en kolonihave normalt skulle overdrages til kommunen eller en af dens institutioner, var der en række juridiske og økonomiske regler, der skulle overholdes, ligesom sagen skulle behandles politisk. Der fulgte juridiske og økonomiske forpligtelser med, som at kolonihaveforeningen skulle godkende overdragelsen, der ville være en række løbende økonomiske forpligtelser forbundet med at have kolonihaven osv. Sådanne juridiske og økonomiske dispositioner kunne Fyrtårnet ikke umiddelbart selv indgå. De skulle godkendes og behandles af kommunen, der skulle styre transaktionen igennem. Dette kunne tage sin tid og ikke være helt ukompliceret.

Erna havde ringet til borgmesteren, der havde videreformidlet tilbuddet om kolonihaven til Fyrtårnet, der sagde ja tak til at modtage gaven. Med kommunens udsagn "Det forekom enkelt, da der så i den anden ende var en daginstitution, der sagde ja tak. Så var det lige pludselig dem, der skulle håndtere alle de spørgsmål” etablerede kommunen en fremtid for samarbejdet, hvor den trådte tilbage fra sin styring af overdragelse af gaven og lod Fyrtårnet og Erna selv klare denne. Kommunen etablerede Fyrtårnet som den handlende, der kunne modtage kolonihaven som gave. Kommunen suspenderede sig som politisk system for at række ud mod Fyrtårnet og lade det selv tage styringen på sig. 
Med kommunens udsagn "De spørgsmål ville man søge svar på, inden at man ville forelægge dem til politisk behandling... Her skete noget andet", blev overdragelsen af kolonihaven udtryk for noget andet end kommunens styring af den selvejende daginstitution. Analysen viser, at med aktivering af foregribende koblinger gjorde kommunen sig omverdens følsom for Fyrtårnet, og gaven blev symbol på kærligheden fra et politisk system, der ville bane vejen for Fyrtårnets og Ernas drømme. Kommunen havde ikke først og fremmest øje for sit eget behov for styring, men på Fyrtårnets og Ernas behov for, at det skulle være enkelt at kunne give og modtage en kolonihave.

Fyrtårnet var bevidst om, at netværket selv ville komme til at håndtere det juridiske, økonomiske og praktiske omkring overdragelsen af kolonihaven, men også, at det havde kommunen til at supervisere og foregribe, hvad der måtte være af udfordringer. Med udsagnet "kommunens opbakning har været et vigtigt element i den sammenhæng. Jo mere vi kan gøre selv, jo mere støtter de op omkring det", satte Fyrtårnet en fremtid for samarbejdet med kommunen med tillid til, at kommunen ville understøtte processen om overdragelse af kolonihaven.

Analysen viser også, at Fyrtårnet aktiverede foregribende koblinger og knyttede an til kommunens kommunikation ved at suspendere sig selv som pædagogisk og omsorgssystem for at række ud mod kommunen og tage selvstyring på sig. Fyrtårnet håndterede det praktiske omkring overdragelsen af kolonihaven og gjorde den til et sted for pædagogisk udfoldelse og civilsamfund med forældre og interessenter. Hermed rakte Fyrtårnet tilbage i sig selv som pædagogisk system og omsorgssystem på en ny måde. Nu havde den en kolonihave i bagagen for en udvidet pædagogisk praksis i institutionen.

Kolonihaven blev en del af kommunens daginstitutionsydelse inden for åbningstiden og et sted for integration og civilsamfundsengagement uden for åbningstiden. For kommunen blev Fyrtårnet en dannelsesinstitution for børnene i forhold til at lære om det aktive medborgerskab, og at ikke alle velfærdsinitiativer skulle styres fra et rådhus. Lige pludselig var der ikke kun tale om et samarbejde mellem Fyrtårnet og kommunen, hvor Fyrtårnet fik en gave af en ældre dame. Socialdimensionen havde ændret sig i samarbejdet, hvor andre parter fra lokalsamfundet koblede sig på med at hjælpe til med kolonihaveprojektet. Sagsdimensionen havde ændret sig i forhold til, at samarbejdet med driftsoverenskomsten drejede sig om at drifte daginstitutionsydelsen. Nu kom denne til også at dreje sig om en dagtilbuds- og frivillighedspolitik, der ikke var født af nogen forvaltning eller i et politisk udvalg, og som ikke kunne reduceres til kommunens formelle beslutninger herom.

Det var en dagtilbuds- og frivillighedspolitik, der gjorde det muligt for kommunen at nå længere ud og skumme et særligt potentiale i forbindelse med de selvejende daginstitutioners levering af deres velfærdsydelse. De selvejende daginstitutioner både gjorde, hvad kommunen sagde, men var også 
selvstændige, og dette paradoks blev hverken forskubbet eller udskudt, men stod bare og lyttede og dirrede. Både kommunen og Fyrtårnet var blevet forvandlet med et samarbejde, der havde aktiveret enkle, flygtige og foregribende koblinger, der involverede og udfordrede grænserne for parternes identitet.

\section{G. Hvad der kan læres af MDI-partnerskabsprojektet}

Med MDI-partnerskabsprojektet kom der et nyt ideal i spil for samarbejdet mellem selveje og kommune. Det kunne referere til juridiske og økonomiske koder med driftsoverenskomst og dagtilbudslov med normativ forudberegnelighed i forhold til sagsdimensionen om at drifte daginstitutionen og socialdimensionen som kommune og selveje med en tidslighed, der rakte bagud til dengang, parterne indgik driftsoverenskomsten. Det kunne imidlertid også referere til andre strukturer for samarbejde, der ville række frem i tid. Disse kunne udvikle socialdimensionen om hvem, der var parter i forbindelse med daginstitutionsopgaven og sagsdimensionen i forhold til, hvad denne gik ud på. Som betingelse for et sådan samarbejde ville det oscillere mellem enkle, flygtige og foregribende koblinger som en måde at drifte og samtidig afsøge potentialet i et nyt samarbejde mellem selvejende daginstitutioner og kommunen.

Modsat en regulering med driftsoverenskomst og dagtilbudslov med en normativ forudberegnelighed blev parterne selv den største kilde til stabilitet og ustabilitet for det nye ideal om samarbejdet mellem selveje og kommuner. For dette kom til at afhænge af, hvordan et samspil mellem parterne blev håndteret som enkle, flygtige og foregribende koblinger, og den måde de orienterede sig efter hinanden. Det var ikke en regulering af samarbejdet, der umiddelbart var genkendelig som retslig semantik, men som alligevel var forudsætningen herfor. Det var en hybrid ret, der ville kunne sætte betingelserne for retten i forhold til samarbejdet, som det ville kunne blive i fremtiden. Om denne fremtid var tæt på eller langt væk ville afhænge af, hvordan samspillet mellem parterne udfoldede sig med enkle, flygtige og foregribende koblinger.

Det var et nyt ideal for samarbejde mellem selveje og kommuner, der skulle læres. Det stillede krav til deltagerne at involvere sig med, og det kom også til at trække grænsen for dets udbredelse i partnerskabsprojektet. Det havde ikke en normativ forudberegnelighed som et samarbejde, der alene var reguleret over driftsoverenskomsten og med reference til dagtilbudsloven. Der var ikke noget autoritativt center med partnerskabet som medie for en vekselvirkning mellem enkle, flygtige og foregribende koblinger. Det gjorde samarbejdet til noget, der ikke var stabilt, og som kunne referere både til dette som i en fortid og som noget, der skulle udvikles i fremtiden. Det kunne håndtere og bearbejde stor kompleksitet, men det stillede også krav at involvere sig med. Dette etablerede en spænding, men det blev også partnerskabets energi, der risikerede at gøre noget grundlæggende ved både selvejes og 
kommunens identitet som betingelse for et samarbejde, der kunne indløse et potentiale og kvalitetsløft i forbindelse med velfærdsydelsen.

\section{H. Samarbejde som samskabelse med sommerfugle-modellen}

Luhmann ser et problem som en arena, der gør det muligt at sammenligne flere løsninger og for den sags skyld også flere problemer til den samme løsning, og at man ikke kan diskutere kausalitet på en bestemt deterministisk måde (Luhmann 2000: 91; Knudsen 2011, 2014). Det studerede MDI-partnerskabsprojekt vil f.eks. dukke op som løsningen på et problem i forhold til samarbejdet over driftsoverenskomsten, men de underliggende spændinger eller paradokser forsvinder ikke bare, men bliver ved med at være til stede på forskellig vis eller dukker op på nye måder.

Jeg vil imidlertid argumentere for at fremlægge en normativ model som et nedslag på denne arena, som jeg benævner sommerfugle-modellen og udleder af analysens resultater. For at kunne opstille modellen udvælger og antager jeg som iagttager af det studerede partnerskabsprojekt bestemte kausalsammenhænge på de betingelser, at alle iagttagelser og selviagttagelser er bundet til at producere paradokser. Det gælder selvfølgelig også mine.

Paradokser var også et grundvilkår for samarbejdet mellem selveje og kommuner i det studerede MDIpartnerskabsprojekt, som projektet ved at aktivere en vekselvirkning mellem enkle, flygtige og foregribende koblinger kunne gøre produktive, hvor paradokserne ikke bare blev skubbet eller gemt bort, men stod og dirrede. Sommerfugle-modellen er udtryk for et samarbejde baseret på denne paradokshåndtering som strategier for et nyt samarbejde, som jeg vil forstå som samskabelse, fordi det kan løse op for spændinger og indløse et velfærdspotentiale.

I stedet for alene at vægtlægge samskabelse som et resultat, der som et æble kan måles og vejes i forhold til forskellige bundlinier (Tortzen 2019:58), foreslår jeg med afsæt i min undersøgelse med sommerfuglemodellen en anden tilgang til samskabelse, hvor der også kigges på det æbletræ, hvorfra der plukkes frugter. Med en sådan tilgang til samskabelse rettes fokus mod de processer, der er forudsætningen for, at et samarbejde kan transformeres til samskabelse mellem selvejende og frivillige organisationer. For som Dahler-Larsen siger, har guden Janus to hoveder, der kigger i hver sin retning, og nøglerne holder han i sine hænder (2018). Dette er mit bud til nøglerne, der kan operationalisere og transformere et samarbejde til samskabelse. 


\section{Sommerfugle-modellen i fem trin}

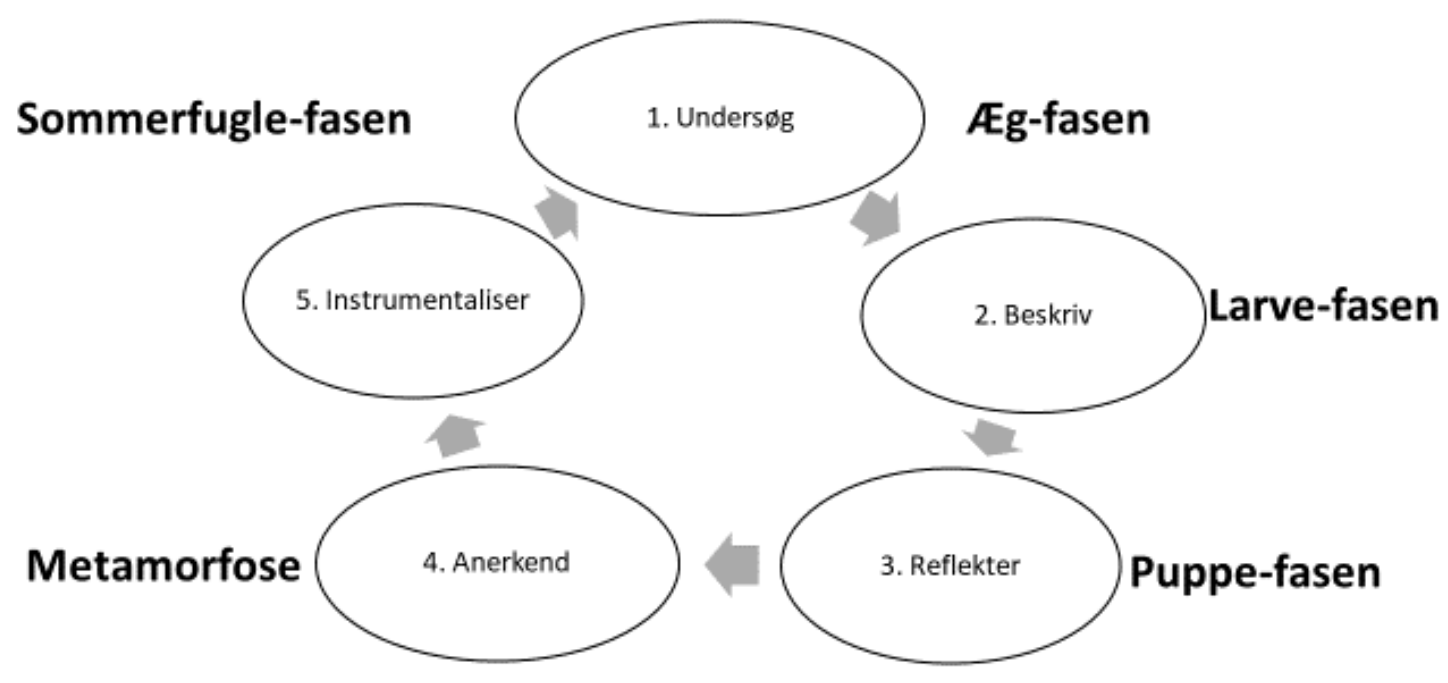

Figur: Sommerfugle-modellen

I kålormen er der en celle, der kaldes den imaginære celle, fordi den har en særlig DNA kodning, som gør, at den - når tiden er inde - kan sætte den celletransformation i gang, som forandrer kålormen til sommerfugl. På samme måde er sommerfugle-modellen det DNA, der kan transformere samarbejde til samskabelse og samarbejdets imaginære celle. Det er en model, der forbinder et vertikalt med et horisontalt niveau, der i en vekselvirkning kan sætte retning for hinanden. Modellen indebærer fem trin, som ikke er nogen, der skal gennemføres en gang for alle og udpeger en fortsat proces, der må gentages igen og igen som betingelse for, at samarbejdet transformeres til samskabelse og holdes levende.

\section{1. Æg-fasen}

\section{Trin 1. Undersøg}

Æg-stadiet er sommerfuglens første stadie, og det første skridt i at kigge på samarbejdet på en ny måde. Ved at aktivere enkle og flygtige koblinger i samarbejdet lyttes og forklares problemerne omkring samarbejdet uden, at der laves beslutninger om, hvordan disse skal løses. Beslutningen om, på hvilke betingelser, der kan og skal samarbejdes, udstrækkes. Beslutningsrummet skal nemlig først informeres i forhold parterne socialt i forhold til hvem, det er, der samarbejder, hvad der sagsmæssigt samarbejdes om, og hvilken tidshorisont samarbejdet refererer til.

Som et eksempel havde de fire selvejende daginstitutioner i netværket Fyrtårnet og deres kommune gennem længere tid været på kant med hinanden. Kommunen syntes, at de selvejende 
daginstitutioner ikke ville samarbejde ordentligt i forbindelse med krav om besparelser og faglighed. De betalte trods alt institutionerne for at levere en daginstitutionsydelse, der var reguleret i driftsoverenskomsten og lovgivningen. Institutionerne syntes omvendt, at kommunen blandede sig alt for meget i forhold til, hvordan de skulle håndtere arbejdet med børnene, og at der væltede unødvendige bureaukratiske regler ned over dem. Uenigheden havde ført til, at der kørte en del i lokalpressen, og både institutionerne og kommunen brugte rigtig meget tid på at skændes i offentligheden og på stormøder. Nu besluttede netværket Fyrtårnet og kommunen sig til at gå i gang med et samarbejde baseret på partnerskab. De besluttede sig til at starte med at lytte og forklare, hvordan de respektivt så på udfordringerne i samarbejdet, og hvad der gensidigt pressede dem ikke kun i forhold til en bagudrettet tidshorisont, der refererede til den driftsoverenskomst, der engang var blevet indgået, men også i forhold til nye ting, der var kommet til af betydning for samarbejdet i forhold til daginstitutionsydelsen og parterne.

\section{Larve-fasen}

Trin 2. Beskriv

Når larven er klækket, begynder den at bevæge sig gennem tilværelsen på en særlig måde, hvor den spiser de planter, der er omkring den på samme måde, som et samarbejde vil forbruge ressourcer på forskellig vis. Parternes forskellige perspektiver på samarbejde undersøges med aktivering af enkle og flygtige koblinger. Formålet er at kategorisere de koder, der er i spil, og hvad der sker, når koder skifter, og beslutningsrummet ændrer sig. Det beskrives, hvilke konsekvenser dette har for samarbejdet.

I eksemplet beskrev kommunen i denne fase, at der var krav om besparelser, et mere effektivt ledelseslag og dokumentation som følge af nye læreplaner, der skulle sikre fagligheden i institutionen. Fra kommunens side var der flere koder i spil. Der var både en politisk kode om at styre daginstitutionerne, en juridisk kode, om at der var lovgivning, der stillede krav og en faglig kode om dokumentation af kvaliteten i det pædagogiske arbejde. Der var også en økonomisk kode i spil i forhold til besparelser. Hos netværket Fyrtårnet var der også forskellige koder i spil. Der var en omsorgskode i form af, at forældre og ledelse insisterede på at give omsorg til børnene på egne betingelser. Der var en politisk kode om at ville styre sig selv. Endelig var der juridiske og faglige koder, der med lovgivning stillede krav til daginstitutionens pædagogiske arbejde, men også til, at denne kunne have en vis autonomi. De forskellige koder, der var på spil på én gang hos parterne blev kortlagt. Dette for at skabe forståelse for, hvordan de kunne skabe spændinger og støde sammen i forhold til det samarbejde, der både refererede til kontrakt og lovgivning, der blev aftalt tilbage i tid, men som blev udfordret, fordi noget, der ikke var forudset på dette tidspunkt, kom til at påvirke samarbejdet ind i en fremtidig horisont. 


\section{Puppe-fasen}

Trin 3. Reflekter

Når larven er klar til at forpuppe sig, finder den et egnet sted og spinder sin silketråd til puppen. I denne fase er parterne kommet så langt, at det potentielle beslutningsrum er blevet grundigt informeret med enkle og flygtige koblinger. Samarbejdet kører stadig over driftsoverenskomst og dagtilbudslov, og der er endnu ikke truffet beslutninger om nogen nye tiltag. Nu går udvekslingen af information imidlertid ind i en ny fase. Det drejer sig ikke længere om kun at fremlægge synspunkter, udfordringer, drømme og ambitioner med samarbejdet fra sit eget synspunkt. Det drejer sig om også at aktivere foregribende koblinger og at sætte sig i den andens sted og gøre dennes positioner lige så vigtige som ens egne. For det er nu, at forudsætninger for de senere transformationer i samarbejdet mellem parterne skabes. Det er nu, at tråden spindes hertil.

I denne fase reflekteres over, hvad de forskellige koder i samarbejdet betyder for samarbejdet. Der arbejdes med scenarier for, hvordan samarbejdet kunne være anderledes ved at inddrage den andens perspektiv eller andre indsigter, der er kommet frem i løbet af den foreløbige proces fra andre parter eller niveauer af relevans for samarbejdet. Der refereres ikke kun til samarbejdet i forhold til de parter, der i sin tid indgik en aftale om at samarbejde om en bestemt sag på bestemte betingelser. Der tales også om de ting, der er kommet til undervejs, som ikke var forudset, men har udfordret det. Der tales om dem, der vil kunne komme, og hvem det vil være en god ide at inddrage som parter til at håndtere dette.

I eksemplet satte forskellige organisatoriske niveauer hos netværket Fyrtårnet og kommunen sig i hinandens sted og fortalte, hvad spændinger og paradokser gjorde ved samarbejdet. Lederne gik på uddannelse i, hvordan de kunne lave en partnerskabsaftale med kommunen og gik i dialog med kommunen herom. Begge parter fik hermed styrket en refleksiv kompetence som forudsætning for at kunne gå til samarbejdet med et nyt blik. Netværket mødtes med kommunen på forskellige niveauer med deres ledere, bestyrelser og paraplyorganisation. Parterne hjalp hinanden med at åbne egen verden op og gøre den forståelig for den anden. Følgeforskning på partnerskabsprojektet informerede yderligere parternes refleksion. De koder, der var i spil i forbindelse med samarbejdet og vigtige for den enkelte, blev oversat for den anden. Forskellige organisatoriske niveauer kom til at sætte retning og inspirere hinanden.

\section{Metamorfose}

Trin 4. Anerkend

Når larven har lavet sin puppe, sker den forvandling, der kaldes metamorfose hvor samarbejdet kommer til at veksle mellem at være reguleret af kontrakt og lovgivning, men også aktiverer en vekselvirkning mellem enkle, flygtige og foregribende koblinger. Fra at bestå af celler med et DNA, der konstant skabte og genskabte kålormen, aktiveres nu den imaginære celle, der bliver styrende 
for metamorfosen. Larven går i opløsning, og ud af denne væske finder cellerne sammen og danner det, der bliver til den voksne sommerfugl. For samarbejdet betyder dette, at det nu går i gang med at transformere sig. Fra alene at se samarbejdet reguleret af driftsoverenskomst og dagtilbudslov anerkendes det, at beslutningsrummet, som beskriver de forskellige konkurrerende og evt. modsatrettede hensyn, må udstrækkes og informeres i fællesskab. Det anerkendes også, at den andens perspektiv må være med til at forme betingelserne for, hvordan ens eget udsyn kommer til at blive. Metamorfosen kan nu indfinde sig og forvandle samarbejdet til samskabelse.

\section{Sommerfugle-fasen}

\section{Trin 5. Instrumentaliser}

Når puppestadiet er overstået, revner puppen, sommerfuglen kryber ud, og vingerne tørrer. I dette sidste trin drejer det sig i forhold til samarbejdet om at afveje og diskutere usammenlignelige hensyn og koder og give plads til at udvikle nye løsninger, fordi rummet er åbnet op med nye indsigter om hinandens positioner. Det er nu, at en vekselvirkning mellem enkle, flygtige og foregribende koblinger danner afsæt for at træffe beslutninger, sådan at samarbejdet kan komme ud og flyve på en anden måde. Det er imidlertid vigtigt at understrege, at det er en særlig slags beslutninger. For parterne ved, at de skal mødes igen, og at det rum for samarbejde, der er etableret, er helt afgørende for, at der løbende vil kunne udvikles gode løsninger. Alle ved også, at den løsning, der vælges nu, vil kunne og skulle bearbejdes senere og hen af vejen. For de fem trin er ikke en engangsforestilling. Det er en måde at stå i samarbejdet på.

I eksemplet blev det muligt for Fyrtårnet at modtage en kolonihave og inddrage den som led i sit pædagogiske arbejde og med civilsamfund. Dette blev støttet af kommunen, selvom det ikke umiddelbart var en del af kommunens dagtilbudspolitik, driftsoverenskomst eller lovgivning, at daginstitutioner skulle arbejde med kolonihaver. Det var blevet muligt at skære igennem med løsninger og handlinger på baggrund af et informeret beslutningsrum bestående af en vekselvirkning mellem enkle, flygtige og foregribende koblinger som forudsætning herfor, der havde aktiveret en anden måde at samarbejde på, end når det alene refererede til driftsoverenskomst og lovgivning. Samarbejdet blev medie for en social og daginstitutionspolitik, som ingen havde tænkt på før, hvor enlige mødre og etniske minoriteter med børn i institutionen kunne lære om værdien ved små haver og komme sammen uden for institutionens åbningstid, og som del af det pædagogiske arbejde med børnene i åbningstiden. Det var en måde at samarbejde på, der forløste et velfærdspotentiale, ingen havde regnet med. 


\section{J. Modellens begrænsninger og potentiale}

Når der udpeges én normativ løsning på et spændingsfuldt samarbejde mellem selveje og kommuner med en sommerfugle-model, som det styrende DNA for et samarbejde som samskabelse må udfolde sig igennem, kan det altid siges at være en dårlig beslutning fra det ene eller andet perspektiv eller en god beslutning. Det er imidlertid min ambition med modellen at udnytte den åbenhed, der ligger i, at der overhovedet kan ses flere løsninger på et problem, og at det med systemteorien er muligt at komme tættere og tættere på en forståelse heraf (Frankel \& Thygesen 2012; Esposito 2011:20-23).

Det kan også anføres, at jeg alene har studeret ét partnerskabsprojekt og alligevel kaster mig ud i modeludvikling. Det gør jeg med en reference til Popper og Flyvbjerg, der med det berømte eksempel om den sorte svane diskuterer et enkelt casestudies potentiale for generaliserbarhed (Popper 2005; Flyvbjerg 2006, 2010). Eksemplet handler om, at udsagnet "alle svaner er hvide" kan falsificeres med observationen af bare én sort svane. Jeg har ønsket at forfølge, at der er mulighed for at udvikle sorte svaner med sommerfugle-modellen, og hvad det indebærer for samarbejdet i forhold til, at dette alene finder sted over driftsoverenskomsten.

Systemteoretiske forskere diskuterer, at velfærdssamfundet i dag er kendetegnet af en række forventninger til opgaveløsningen med faglig pluralisme, tværgående løsninger, inddragelse af borgerne og udvikling som en del af udførelsen af velfærdsopgaven. Retten, der skal regulere dette samarbejde, beskriver særligt Sand og Teubner som uddifferentieret fra formel ret til substantiel ret og videre til refleksiv ret, hvor retten gradvist har trukket sig tilbage og åbnet sig for retsfremmende hensyn og andre funktionssystemer såsom hybrid ret. Samtidig forbinder samarbejdet netværk på forskellige planer (Sand 2012, 2009; Teubner 2009, 2002, 1996, 1994, 1988; Højlund 2002).

Som et bidrag til denne forskning argumenterer jeg for, at når retten i gamle dage fungerede med normativ forudberegnelighed for at håndtere konflikter mellem selveje og kommuner med driftsoverenskomst, kontrakt og lovgivning, så må retten, for fortsat at fungere i det moderne velfærdssamfund, også ændre sig. Retten må etablere nye strukturer for, hvordan samarbejdet kan jonglere med både forudsigelighed og det uforudsigelige som betingelse for samarbejde om velfærdsopgaven. Retten, der på forskellig vis regulerer samarbejdet, bliver hverken uvedkommende eller kommer til at stå i vejen for samarbejdets fornyelse som samskabelse, men antager en hybrid form.

For når der med sommerfugle-modellen aktiveres særlige samarbejdslogikker, der ikke er reguleret af lovgivning eller kontrakt, er der ikke tale om en ret, der abdicerer, når den trækker sig tilbage. 
Det er en ret, der træder op på ny i forhold til at regulere samarbejdet på indirekte vis gennem de samarbejdende organisationer. De organisationer, der ønsker at samarbejde på denne måde, må arbejde for, at de relevante samarbejdslogikker aktiveres hos hinanden. Det er et forhandlet samarbejde, der kan blive til et magtfuldt fænomen, hvor forskellige rationaler vil kunne emergere og kollidere, men også spille sammen på forunderlig vis; hvor paradoksale krav i samarbejdet ikke bare skubbes og udskydes, men gøres produktive og forbinder sig på operationelt og policy niveau. Det drejer sig om at håndtere de muligheder, der dukker op, og være åben overfor, hvordan de dukker op.

Parterne bliver særlig følsomme for hinanden, da det er afgørende, at den enkelte organisation evner at sætte sin egen organisation på spil. De involverede organisationer skal kunne mobilisere en refleksiv kapacitet til selv at kunne regne ud, hvad der forventes, tage initiativer og foregribe den anden organisations ønsker og behov i forbindelse med samarbejdet. Det handler ikke kun om at efterleve krav i driftsoverenskomsten, lovgivning og kommunens dagtilbudspolitik, men om organisationens evne til at foregribe den anden organisations behov, førend nogen har bedt om det. Driftsoverenskomsten, der beskriver rettigheder og pligter, er blevet skubbet i baggrunden som ret, og i stedet må der konstant svares og bydes ind som led i samarbejdet. Det sætter en forventningshorisont om løbende at tage ansvar for selvstyring og mægtiggørelse i forhold til at indløse et samarbejde om velfærdsopgaven. Hermed etableres der et anderledes forpligtende element i samarbejdet, som også indlejrer usikkerhed i forhold til, hvornår man har gjort nok.

Mobilisering hertil kræver involvering og motiverede deltagere hos både selvejende frivillige organisationer og kommuner, der skal være indstillede på at lade et operationelt niveau forbinde sig med et policy niveau. Sagen er bare, at de involverede deltager af forskellige årsager. Det at få dem bragt ind på en fællesnævner, hvor der både er plads til at være sig selv og til at udvikle noget nyt sammen, kræver håndarbejde omkring modellens fem trin. Det udfordrer, hvordan kompetencer og ansvar fordeles med sådan et samarbejde, og at parterne lærer det og bliver enige om, at det er den form for samarbejde, som de ønsker og bliver ved med at ønske. For alle kan jo i princippet tage ansvar for en ny måde at samarbejde og samskabe på, men alle kan også lade det ligge. Det at sikre løbende afstemning af forventninger og tilslutning bliver centralt både horisontalt og vertikalt. For ingen kan sige, hvilke organisationer der vil eksistere inden for selveje og kommuner i morgen, og hvordan de ville gøre sig relevante i forhold til at samarbejde om velfærdsopgaven. Disse organisationer og betingelserne for samarbejde og samskabelse må konstant skabes og genskabes i nutiden i lyset af forventninger om fremtiden, der flygtigt og hurtigt forfalder.

Et samarbejde med sommerfugle-modellen kan skabe ny retning og et handlerum for parterne, men det vil også kunne belaste samarbejdet, hvis de ikke forstår, hvad dette kræver. Der må frigøres ressourcer hertil på de forskellige niveauer i partnerskabet. Det er noget, der skal læres, og det 
kræver tålmodighed og tid at udvikle. Det kan udfordre et samarbejde over driftsoverenskomsten og lovgivning, der er reguleret med retten med forudberegnelighed og en bagudrettet tidslighed, der hovedsageligt retter sig mod et operationelt niveau. Det kan imidlertid også indløse et potentiale i samarbejdet om velfærdsopgaven, som, hvis det hovedsageligt er styret af en økonomisk og juridisk bagudrettet logik, vil være langt vanskeligere.

\section{K. En platform mellem praksis og universitet}

I kålormen findes der de særlige celler, der hedder de imaginære celler. Selvom disse grundlæggende deler det samme DNA som kålormen, er de også forskellige herfra, for de indeholder det, som en dag vil forandre kålormen til en sommerfugl. I første omgang opfatter kålormens immunsystem dem som en trussel, og angriber dem for at undertrykke, at de bliver aktiveret. Når tiden er inde, begynder de imaginære celler imidlertid at dele sig og forbinde sig til hinanden til den sommerfugl, kålormen er på vej til at blive. I puppestadiet bliver kålormen til næring for denne transformationsproces.

Modsat kålormens transformationsproces giver det ikke sig selv, hvornår tiden er inde til at lade samarbejdet om velfærd mellem selvejende frivillige organisationer og kommuner transformere sig til samskabelse. Parterne må selv etablere forudsætningerne for transformationen. Det at fremelske de institutionelle tiltag, der er nødvendige herfor, er ikke noget enkelt forehavende. Sådanne transformationsprocesser sker i sommerfugleverdenen først, når der har været et slags sammenbrud. Det at være kålorm går ikke længere.

Med en parallel til, hvordan vi bruger og forbruger ressourcer $\mathrm{i}$ forbindelse med velfærdsproduktionen og de mennesker, der er en del heraf i vores samfund, kan man sige, at det heller ikke går længere. Der, hvor vi skal hen for at gøre tingene anderledes, eksisterer bare heller ikke endnu. Når en kålorm forpupper sig, holder den op med at spise, mens den undergår sin metamorfose. Denne tilstand kan vare fra dage til mange måneder.

Sådanne transformationsprocesser er skrøbelige, og jeg argumenterer derfor for en platform mellem praksis og universitet, hvor sommerfugle-modellen er den frekvens, parterne er nødt til at komme ind på, hvis de vil transformere deres samarbejde til samskabelse mellem selvejende frivillige organisationer og det offentlige og en forebyggende praksis omkring det psykiske arbejdsmiljø. En platform, der skal understøtte og passe på pupperne hos dem, der går i gang hermed sammen med fødselshjælpere i form af uddannelser, forskning i partnerskaber, samskabelse, transformationsprocesser, ny anerkendelsespraksis og møder mellem forskning og praksis på forskellige planer om alt dette. 
Med sommerfugle-modellen og forslaget om platform ønsker jeg at bidrage til, at praktikere og interessenter inden for velfærdsområde kan iagttage, hvordan det samarbejde, der gennem årtier hovedsageligt har været reguleret af kontrakt og lovgivning, kunne se anderledes ud og bidrage til samskabelse. Samtidigt er det vigtigt for mig at understrege, at det er et samarbejde, der altid vil være i sin skabelse, hvorfor det er vigtigt at kunne indløse løbende refleksion hos parterne om, hvad der gør det relevant, og hvordan det udspiller sig, udfordres, udvikles og kommer til at flyve. Der er ikke nogen endegyldig sandhed herpå, men det er muligt at stå i samarbejdet på en anden måde i forhold hertil.

\section{Om forfatteren:}

Charlotte Biil, cbi.mpp@cbs.dk, er cand.jur., advokat, Master in Public Administration og har et ph.d.-stipendiat og forskningsprojekt hos Institut for Ledelse, Politik og Filosofi på CBS om partnerskaber mellem selvejende og frivillige organisationer og det offentlige. Hun forventer at forsvare sin ph.d. omkring sommeren 2020. Charlotte Biil har gennem mange år arbejdet både som praktiker og forsker med velfærdspartnerskaber og har været med til at stifte Selveje Danmark, hvor hun er næstformand. Hun varetog arbejdsmiljøområdet i Dansk Erhverv gennem en årrække og har stor erfaring i partssamarbejde. Hun har på CBS arbejdet som projektleder på partnerskabsdelen i forbindelse med Pernille Steen Pedersens forskningsprojekt om en ny anerkendelsespraksis til forebyggelse af stress-relateret sygefravær med Forhandlingsfællesskabet og Fremfærd. 


\section{Referencer}

Aagaard, P., Sørensen, E. \& Torfing, J. (2014). Samarbejdsdrevet innovation i praksis. København: Jurist- og Økonomforbundets Forlag.

Alford, J. (2009). Engaging Public Sector Clients. From service delivery to co-production. Basingstoke: Palgrave Macmillan.

Alvesson, M. \& Kärreman, D. (2007). Constructing mystery: empirical matters in theory development. Academy of Management Review 32. https://doi.org/10.5465/amr.2007.26586822

Alvesson, M. \& Kärreman, D. (2011). Qualitative Research and Theory Development: Mystery as Method. Sage. https://doi.org/10.4135/9781446287859

Alvesson, M. \& Sköldberg, K. (2009). Reflexive Methodology. New Vistas for Qualitative Research. Sage Publication.

Andersen, Niels Åkerstrøm \& Born, W., Asmund (2001). Kærlighed og omstilling - italesættelsen af den offentligt ansatte. København: Nyt fra Samfundsvidenskaberne.

Andersen, Niels Åkerstrøm \& Pors, Justine Grønbæk (2014). Velfærdsledelse mellem styring og potentialisering. København: Hans Reitzels forlag.

Andersen, Niels Åkerstrøm \& Pors, Justine Grønbæk (2016). Public management in transition. The Orchestration of potentiality, Policy Press, Bristol, UK.

Andersen, Niels Åkerstrøm \& Pors, Justine Grønbæk (2017). On the history of the form of administrative decisions: how decisions begin to desire uncertainty, Management \& Organizational History, Vol. 12, no. 2, pp. 191-141, https://doi.org/10.1080/17449359.2017.1324800

Andersen, Niels Åkerstrøm (1999). Diskursive analysestrategier: Foucault, Koselleck, Laclau, Luhmann. København: Nyt fra Samfundsvidenskaberne.

Andersen, Niels Åkerstrøm (2006). Partnerskabelse. Copenhagen: Hans Reitzels forlag.

Andersen, Niels Åkerstrøm (2008). Partnerships: Machines of possibility, Policy Press, Bristol.

Andersen, Niels Åkerstrøm (2012). To promise a promise: When contractors desire a life-long partnership. I: Niels Åkerstrøm Andersen \& Inger-Johanne Sand, 2012 (ed): Hybrid forms of governance -Self-suspension of power, Palgrave Macmillan, London, p. 205-231. https://doi.org/10.1057/9780230363007_12

Biil, C. (2020 forthcoming). En bæredygtig partnerskabsmodel. Partnerskabet som hybrid ret og temporaliseret samarbejde i forbindelse med et partnerskabsprojekt mellem 100 selvejende daginstitutioner, deres paraplyorganisation og tre kommuner. PhD. CBS. 
Biil, C., Christiansen, S. \& Kyst, M. (2006). Hvorfor ikke udbyde til selvejende daginstitutioner? København: Frie Børnehaver og Fritidshjem.

Biil, C., Christiansen, S. \& Kyst, M. (2007). Konkurrencevilkår for selvejende daginstitutioner i et kommunalt domineret marked - konkurrenceretslige refleksioner og cases. København: Frie Børnehaver og Fritidshjem.

Boje, P. Fridberg, Torben, Fridberg, Thomas og Ibsen, Bjarne (2006). Den frivillige sektor i Danmark - omfang og betydning. København: Socialforskningsinstituttet.

Born, A., Bredsdorff, N., Hansen, L. og Hansson, F (1988) (ed.). Refleksiv ret. Frederiksberg: Nyt fra samfundsvidenskaberne.

Bovaird, T. \& Löffler, E. (2012). From engagement to co-production: The contribution of users and communities to outcomes and public value. Voluntas, 23(4), 1119-1138. https://doi.org/10.1007/s11266-012-9309-6

Brink Lund, A. \& Enevold Berg, C. (2016). Dansk Fondshistorie. København: Jurist- og Økonomforbundets Forlag.

Bundesen, Peter, Henriksen, Lars Skov og Jørgensen, Anja (2001). Filantropi, selvhjælp og interesseorganisering - Frivillige organisationer i dansk socialpolitik 1949-1990'erne. Odense: Odense Universitetsforlag.

Carstensen, H.V., Hjelmar, U. \& Jeppesen, L.K. (2017). Innovationsevaluering - når resultatmålinger understøtter reel innovation. Økonomistyring \& Informatik, 32(3), 207-222.

Dahler-Larsen, P. (2016). Vejledning om at evaluere innovative tiltag. København: Center for Offentlig Innovation.

Dahler-Larsen, P. (2018). Theory-Based Evaluation Meets Ambiguity: The Role of Janus Variables. American Journal of Evaluation 2018, Vol. 39(1) 6-23. https://doi.org/10.1177/1098214017716325

Dansk Erhverv (2010, 2011a, 2012, 2013, 2014). Social Velfærd.

Dansk Erhverv (2011b) i samarbejde med Blå Kors, ISOBRO, Diakonissestiftelsen, Frelsens Hær, Incita, KFUK, Menighedernes Daginstitutioner og Den Sociale Udviklingsfond. Hvordan inddrages selvejende, frivillige og socialøkonomiske virksomheder bedst muligt i løsningen af fremtidens velfærdsudfordringer? København: Dansk Erhverv.

Dansk Erhverv (2011c) i samarbejde med Blå Kors, ISOBRO, Diakonissestiftelsen, Frelsens Hær, Incita, KFUK, Menighedernes Daginstitutioner og Den Sociale Udviklingsfond. Social Velfærd - Gode løsninger ved brug af ikke-offentlige aktører. København: Dansk Erhverv. 
Esposito, Elena (2011). The Future of Futures: The Time of Money in Financing and Society. England, Northampton: Edward Elgar Publishing.

Flyvbjerg, B. (2006). Five misunderstandings about case-study research. Qualitative inquiry, 12(2), 219-245. https://doi.org/10.1177/1077800405284363

Flyvbjerg, B. (2010). Fem misforståelser om casestudiet. I: Brinkmann, S. \& Tanggaard, L. (red.), Kvalitative metoder: en grundbog. København: Hans Reitzels Forlag. https://doi.org/10.7146/mediekultur.v28i53.5781

Frankel, Christian \& Thygesen, Niels Thyge (2012). Management as a Temporal Hybrid. I: Niels Åkerstrøm Andersen \& Inger-Johanne Sand, 2012 (red): Hybrid forms of governance -Selfsuspension of power. London: Palgrave Macmillan.

Fridberg, Torben \& Skov Henriksen, Lars (2014). Udviklingen i frivilligt arbejde 2004-2012. SFI-Det Nationale Forskningscenter for Velfærd.

Henriksen Skov, Lars \& Bundsen, Peter (2004). Frivilligt socialt arbejde i Larsen (red.), Jørgen Elm,

Hornemann Møller (red.) Socialpolitik, 2004, p. 412-431. København: Hans Reitzels Forlag

Hjære, M. \& Jørgensen, H.E.D. (2017). Tal om kommuner og frivillighed. Analyse af kommunernes engagement og samarbejde på det frivillige velfærdsområde. Odense: Center for Frivilligt Socialt Arbejde. https://doi.org/10.22439/dansoc.v26i2.5048

Højlund, H. \& Biil, C. (2015). Nye veje med partnerskaber I velfærd. CBS.

Højlund, Holger \& La Cour, Anders (2008). Samarbejdets dobbelte strukturer. I: Jesper Tække \& Michael Paulsen (eds.), Luhmann og organisation - teori, empiri og analyse. pp. 177-196. København: Unge Pædagoger. https://doi.org/10.7146/mediekultur.v26i49.2985

Højlund, Holger (2002). Retten som system. LPFLPF Working paper No. 14/2002.

Højlund, Holger (2004). Markedets politiske fornuft. Et studie af velfærdens organisering i perioden 1990-2003. Ph.d.-afhandling. København: Samfundslitteratur.

Ibsen, Bjarne \& Habermann, Ulla (2006). Definition af den frivillige sektor i Danmark. I: Den frivillige sektor i Danmark - omfang og betydning. Boje, Thomas, Fridberg, Torben \& Ibsen, Bjarne (red.). København: Socialforskningsinstituttet. https://doi.org/10.22439/dansoc.v26i2.5049

Knudsen, Morten (2011). Surprised by method-functional method and systems theory. Historical Social Research/Historische Sozialforschung, 124-142. 
Knudsen, Morten (2014). Metodisk overrasket - om systemteori og funktionel metode. I: Harste, Gorm \& Knudsen, Morten (red). Systemteoretiske analyser - At anvende Luhmann. Frederiksberg: Nyt fra samfundsvidenskaberne.

Konkurrencestyrelsen (2010). In-house begrebets betydning for kommunal aftaleindgåelse med selvejende institutioner af 02- 02-2010. København: Konkurrencestyrelsen.

La Cour, Anders (2012). The Love Affair Between the Policy and the Voluntary Organizations. I: Niels Åkerstrøm Andersen \& Inger-Johanne Sand, 2012 (ed): Hybrid forms of governance -Self-suspension of power, Palgrave Macmillan, London p.46-66.

La Cour, Anders (2014a) Frivilliggørelse - Frivillighedens logik og dens politik. København: Nyt fra Samfundsvidenskaberne.

La Cour, Anders (2014b). Den frivillige organisation. I: Vikkelsø, Signe \& Kjær, Peter (red.) Klassisk Og Moderne Organisationsteori, p. 455-475.

Luhmann, Niklas (1985). The Self-Production of the Law and its Limits. I: Teubner, G. (ed.), Dilemmas of Law in the Welfare State, Berlin: Walter De Gruyter.

Luhmann, Niklas (1986). The Coding of the Legal System. I: Teubner, G. \& Febbrajo, A. (ed.), State, Law and Economy as Autopoietic Systems, Milan: Guiffre.

Luhmann, Niklas (1997). Limits of steering. Theory, culture \& society, 14 (1), 41-57.

Luhmann, Niklas (2000). Sociale systemer: grundrids til en almen teori. København: Hans Reitzels forlag. https://doi.org/10.7146/mediekultur.v10i22.1017

Luhmann, Niklas (2002). Politisk styring: et diskussionsbidrag. Grus 23(67),103-108.

Luhmann, Niklas (2012). Love as passion. England Cambridge: Polity Press.

Luhmann, Niklas (2016). Samfundets samfund. København: Hans Reitzels forlag.

Moe, Sverre (1998). Den moderne hjelpens sosiologi. Velferd i systemteoretisk perspektiv. Apeiros forlag.

Moe, Sverre (2003). Tid for Luhmann. En studie av tidens betydning. I: Niklas Luhmanns systemteori og samfunnsanalyse. Institt for sosiologi, Det samfunnsvitenskapelige fakultet, Universitetet i Tromsø.

OECD (2011). OECD Public Governance Reviews: Together for better public services: Partnering with citizens and civil society. Paris: OECD. https://doi.org/10.1787/9789264118843-4-en 
Osborne, Stephen (red.) (2010). The New Public Governance? Emerging perspectives on the theory and practice of public governance. USA and Canada: Routledge. https://doi.org/10.4324/9780203861684

Pestoff, V. \& Brandsen, T. (2010). Public governance and the third sector: opportunities for co.production and innovation? In: Osborne, Stephen (red.) (2010).

Pestoff, V. (2006). Citizens and co-production of welfare services, Public Management Review, 8:4, 503-519, https://doi.org/10.1080/14719030601022882

Pestoff, V., Brandsen, T. and Verschurere, B. (2012). New Public Governance, the Third Sector, and Co-Production. London: Routledge.

Philippopoulos-Mihalopoulos, A. (2003). Suspension of suspension: settling for the improbable. Law and Literature 15.3, pp.345-70. https://doi.org/10.1525/lal.2003.15.3.345

Philippopoulos-Mihalopoulos, A. (2010). Niklas Luhmann. Law, Justice, Society. Oxon: Routledge. https://doi.org/10.4324/9780203872086

Philippopoulos-Mihalopoulos, A. (2012). Suspension of Suspension: Notes on the Hybrid: I Andersen, N.Å. \& Sand, I.J. Hybrid Forms of Governance. Palgrave Macmillan. https://doi.org/10.1057/9780230363007_2

Popper, K. (1996) Kritisk rationalisme: udvalgte essays om videnskab og samfund. København: Nyt Nordisk Forlag Arnold Busck.

Rambøll (2011). Slutrapport om Undersøgelse af selvejende institutioners vilkår og rammebetingelser. Rapport for Socialministeriet.

Regeringen (2011a). Strategi til fremme af offentlig-privat samarbejde. København.

Regeringen (2011b). Regeringens vækststrategi. København.

Sand, I.J. (2009). Retten som medskaper av social mening i komplekse samfunn. I: Aune, H., Fauchald, O.K., Lilleholt, K. Michalsen, D. (ed). Arbeid og rett. Festskrift til Henning Jakhellns 70årsdag.

Sand, I.J. (2012). Hybridisation, Change and the Expansion of Law. I: Andersen, N.Å. and Sand I.J. Hybrid Forms of Governance. Palgrave Macmillan.

Skov Henriksen, Lars (2007). Frivillig organisering: Aktuelle tendenser og fremtidige perspektiver for forskningen. Dansk Sociologi. https://doi.org/10.22439/dansoc.v10i3.728

Sløk, Camilla \& Kaspar Villadsen (red.) (2008). Velfærdsledelse. København: Hans Reitzels Forlag. 
Sørensen, E. \& Torfing, J. (2011). Samarbejdsdreven innovation i den offentlige sektor. København: DJØF Forlaget.

Sørensen, E. \& Torfing, J. (2017). Metagoverning Collaborative Innovation in Governance Networks. Amercan Review of Public Administration. Vol 47(7) 826-839. https://doi.org/10.1177/0275074016643181

Steen Pedersen, Pernille (2016). Udkast til et nyt coping-begreb - en kvalifikation af ledelsesmuligheder for at forebygge sygefravær ved psykiske problemer. CBS. Ph.d.-serie 05/2016

Steen Pedersen, Pernille (2020). Ledelse, kerneopgave og Stress. CBS.

Steen Pedersen, Pernille, Gudmand-Høyer, Marius (2017). Modsatrettede forpligtelser: Skam og stress i arbejdslivet, Erhvervspsykologi, vol. 15.

Teubner, G. (1988). Refleksiv ret. Udviklingsmodeller for retten I sammenlignende perspektiv. I: Born, A., Bredsdorff, N., Hansen, L. og Hansson, F (1988) (ed.). Refleksiv ret. Frederiksberg: Nyt fra samfundsvidenskaberne.

Teubner, G. (1994). The many-Headed Hydra: Network as Higher-Order Collective Actors. I: McCahery, J., Picciotto, S. \& Scott, C. (red.), Corporate Governance and Accountability. pp. 41-60. Oxford: Clarendon Press.

Teubner, G. (1996). Double Bind: Hybrid Arrangements as De-Paradoxifiers. Journal of Institutional and Theoretical Economics, vol. 152: s.59-64.

Teubner, G. (2002). Hybrid laws: constitutionalizing private governance networks. In: Legality and Community, (eds.) R. Kagan, M. Krygier and K. Winston. Berkeley Policy Press.

Teubner, G. (2009). Coincidentia oppositorum: hybrid networks beyond contract and organization. I: Networks, (eds.) G. Teubner and M. Amstutz. Oxford: Hart.

Thøgersen, Malene (2013). Selvejende institutioner i Danmark. Institutionernes udvikling, udbredelse og karakter på udvalgte samfundsområder. CiFri: 01:2013 Arbejdsnotat Netværk for forskning i Civilsamfund \& Frivillighed.

Toft Rasmussen, Elisabeth \& Kock-Nielsen, Inger (1996). Den tredje sektor under forandring. SFI Det Nationale Forskningscenter for Velfærd.

Tortzen, Anne (2019). Samskabelse af velfærd. Muligheder og faldgruber. København: Hans Reitzels forlag.

Udbudsrådet (22. januar 2010). Analyse af barrierer for konkurrenceudsættelse i den offentlige sektor. 
Udbudsrådet (23. marts 2011). Konkurrence på daginstitutionsområdet - erfaringer, muligheder og effekter.

Wied, Kia (2010). Litteraturgennemgang med fokus på netværksledelse. Frederiksberg: Center for Skoleledelse CBS/UCC. 